\title{
IODINE TRANSFER POLYMERIZATION (ITP) OF VINYLIDENE FLUORIDE (VDF). INFLUENCE OF THE DEFECT OF VDF CHAINING ON THE CONTROL OF ITP.
}

Cyrille Boyer, David Valade, Laurent Sauguet, Bruno Ameduri, Bernard Boutevin

\author{
Laboratory of Macromolecular Chemistry
}

Ecole Nationale Supérieure de Chimie de Montpellier (UMR 5076-CNRS)

8, Rue de l'Ecole Normale - F-34296 MONTPELLIER Cedex 1, France

\section{ABSTRACT}

Iodine transfer polymerization (ITP) of vinylidene fluoride (VDF) in the presence of two chain transfer agents (CTA, such as $\mathrm{C}_{6} \mathrm{~F}_{13} \mathrm{I}$ and $\mathrm{HC}_{2} \mathrm{~F}_{4} \mathrm{CH}_{2} \mathrm{I}$ ) is presented. Various experimental conditions in terms of the nature of the radical initiators, time, temperature and initial [initiator $]_{\mathrm{o}} /[\mathrm{VDF}]_{\mathrm{o}}$ and $[\mathrm{CTA}]_{\mathrm{o}} /[\mathrm{VDF}]_{\mathrm{o}}$ molar ratios influenced the yield of the reaction, the obtained average degree of polymerization in number, $\overline{\mathrm{DP}}_{\mathrm{n}}$, of PVDF-I, the defect of VDF-chaining and the $\mathrm{CX}_{2} \mathrm{I}$ functionality (where $\mathrm{X}=\mathrm{H}$ or $\mathrm{F}$ ). The microstructures of these produced PVDF-I oligomers were characterized by ${ }^{1} \mathrm{H}$ and ${ }^{19} \mathrm{~F}$ NMR spectroscopy which enabled one to assess the $\overline{\mathrm{DP}}_{\mathrm{n}}$ values and to quantify the head-to-head or tail-to-tail defects of VDF-chainings. A low amount of defect of chaining in PVDF-I was noted when $\mathrm{C}_{6} \mathrm{~F}_{13} \mathrm{I}$ in contrast to a higher content from $\mathrm{HC}_{2} \mathrm{~F}_{4} \mathrm{CH}_{2} \mathrm{I}$. These PVDF-Is exhibited a favored $-\mathrm{CH}_{2} \mathrm{CF}_{2} \mathrm{I}$ functionality from the former CTA while it was not observed from the latter one. A good agreement between the targeted and the obtained $\overline{\mathrm{DP}}_{\mathrm{n}}$ values was noted for ITP of VDF in the presence of $\mathrm{C}_{6} \mathrm{~F}_{13} \mathrm{I}$ (representative of normal addition) whereas that carried out from $\mathrm{HC}_{2} \mathrm{~F}_{4} \mathrm{CH}_{2} \mathrm{I}$ (representative of inverse addition) led to experimental $\overline{\mathrm{DP}}_{\mathrm{n}}$ values higher than the targeted ones in all cases. A low conversion of $\mathrm{HC}_{2} \mathrm{~F}_{4} \mathrm{CH}_{2} \mathrm{I}$ was observed in contrast to $\mathrm{C}_{6} \mathrm{~F}_{13} \mathrm{I}$, which shows a better efficiency as the transfer agent. 


\section{INTRODUCTION}

In contrast to the radical telomerization of fluoroalkenes ${ }^{1}$, the controlled radical polymerization of such halogenated monomers has led to few investigations. Neither atom transfer radical polymerization (ATRP) ${ }^{2}$, nor nitroxide mediated polymerization (NMP) ${ }^{3}$ of fluoroolefins have been reported in the literature. However, the presence of a chain transfer agent enabled the polymerization to be controlled. Except for one survey involving $x^{x a n t h a t e s}{ }^{4}$, several investigations (mentioned in patent literature mainly) report industrial surveys on the iodine transfer polymerization (ITP) of fluoroalkenes and especially on vinylidene fluoride (VDF) with perfluoroalkyl iodides $\left(\mathrm{R}_{\mathrm{F}} \mathrm{I}\right)$ or with $\alpha, \omega$ diiodoperfluoroalkanes $\left(\mathrm{IR}_{\mathrm{F}} \mathrm{I}\right)$. Indeed, the weak $\mathrm{R}_{\mathrm{F}} \mathrm{CF}_{2}-\mathrm{I}$ bond, the dissociation energy of which is $45 \mathrm{~kJ} \mathrm{~mol}^{-1}{ }^{1}$, enables an easy cleavage rendering both the resulting $\mathrm{R}_{\mathrm{F}} \mathrm{CF}_{2}{ }^{\bullet}$ radical quite reactive and the perfluoroalkyl iodide as an efficient transfer agent hence producing a further VDF adduct with a $-\mathrm{CF}_{2} \mathrm{I}$ end-group. Most chemical industries producing VDF have already protected various discoveries such as the synthesis of thermoplastic elastomers (TPE) pioneered by the Daikin Company in $1979^{5}$ (producing Daiel ${ }^{\circledR}$ TPE $^{6-8}$ ), then studied by DuPont $^{9,10}$ and developped later by Ausimont (now Solvay Solexis) ${ }^{11-13}$. This breakthrough could be possible by the presence of the chain transfer agent and VDF-containing (co)polymer usually made of a soft block that could initiate a further iodine transfer (co)polymerization of one (or two) monomer(s) leading to a soft-b-hard diblock copolymer or hard-b-soft-b-hard triblock copolymers (or thermoplastic elastomers (TPEs)) from $\mathrm{R}_{\mathrm{F}} \mathrm{I}$ or $\mathrm{I}-\mathrm{R}_{\mathrm{F}}-\mathrm{I}$, respectively (Table 1).

\section{Insert Table 1}

In contrast to these industrial progresses, few rigorous scientific investigations have been reported in the literature. Only Tatemoto ${ }^{1,5,14}$ supplied valuable data on the properties and applications of block copolymers, but the description lacks information on the microstructure of the obtained PVDF blocks, on the nature of the end-groups, on the defects of VDF chaining of these produced blocks, and on the evidence of the controlled or "living" behavior of such a polymerization.

Since VDF is an asymmetrical monomer, the produced macroradical generated in the propagation step may add onto $\mathrm{CF}_{2}$ or $\mathrm{CH}_{2}$ sites, considering that an electroattractive 
fluorinated radical should react onto $\mathrm{CH}_{2}$ site taking into account the polar, electronic and steric effects ${ }^{15-17}$. As a matter of fact, it is known that VDF telomers, oligomers, or PVDF contain defects in their microstructures linked to the presence of reversed VDF addition since tail-to-tail, - $\left(\mathrm{CF}_{2} \mathrm{CH}_{2}-\mathrm{CH}_{2} \mathrm{CF}_{2}\right)$-, or head-to-head, $-\left(\mathrm{CH}_{2} \mathrm{CF}_{2}-\mathrm{CF}_{2} \mathrm{CH}_{2}\right)$-, chainings have been observed $^{18-23}$. Hence, it was worth considering the consequence of these reversed additions on the control of ITP of VDF. The use of $\mathrm{C}_{6} \mathrm{~F}_{13} \mathrm{I}$ as the chain transfer agent should lead to two kinds of chains: one terminated by $-\mathrm{CF}_{2}-\mathrm{I}$ as expected, while the other one exhibits a $\mathrm{CF}_{2} \mathrm{CH}_{2}$-I end-group. As a result, quantifying the content of both extremities seems possible. Then, to evaluate the difference of reactivity of both $-\mathrm{CF}_{2}-\mathrm{I}$ and $-\mathrm{CH}_{2}$-I end-groups (arising from the steric and inductive effects), it was worth using another transfer agent, $\mathrm{HC}_{2} \mathrm{~F}_{4} \mathrm{CH}_{2} \mathrm{I}$, for ITP of VDF.

The objectives of this article concern the study of the iodine transfer polymerization (ITP) of VDF with both these different transfer agents and their influence onto the microstructure of the resulting PVDF-I (and hence the correlation between targeted and experimental average degrees of polymerization), the defects of VDF chaining, and the controlled character of ITP polymerization. 


\section{EXPERIMENTAL PART}

\section{Materials}

Vinylidene fluoride and 1,1,1,3,3-pentafluorobutane were kindly supplied by Solvay S.A., Tavaux, France and Brussels, Belgium. Perfluorohexyl iodide (purity 99\%) was kindly supplied by Arkema, France. 1,1,2,2-Tetrafluoro-3-iodopropane (99\%) was purchased from Aldrich Chimie, (38299 Saint Quentin-Fallavier, France). Tert-butylperoxypivalate (TBPPI, purity 75\%) and the 2,5-bis(tert-butylperoxide)-2,5-dimethylhexane (DHBP, 90\%) were gifts from "La Chalonnaise des Peroxydes", Chalons sur Marne, France. They were used as supplied just like acetonitrile (99\%), dimethylformamide (DMF, 99\%), tetrahydrofurane (THF, 99\%) and methanol of analytical grade (99.8\%), from Aldrich Chimie, 38299 Saint Quentin-Fallavier, France.

\section{Analyses}

The compositions and the structures of the oligomers obtained by ITP of VDF were determined by ${ }^{19} \mathrm{~F}$ (200 MHz) and ${ }^{1} \mathrm{H}$ NMR (250 or $400 \mathrm{MHz}$ ) spectroscopies. The NMR spectra were recorded on Bruker AC 200, AC 250 and AC 400 instruments, using deuterated acetone, dimethylsulfoxide (DMSO) and dimethylformamide (DMF) as the solvents and tetramethylsilane (TMS) (or $\mathrm{CFCl}_{3}$ ) as the references for ${ }^{1} \mathrm{H}$ (or ${ }^{19} \mathrm{~F}$ ) nuclei. Coupling constants and chemical shifts are given in $\mathrm{Hz}$ and $\mathrm{ppm}$, respectively. The experimental conditions for ${ }^{1} \mathrm{H}$ (or ${ }^{19} \mathrm{~F}$ ) NMR spectra were as follows: flip angle $90^{\circ}$ (or $30^{\circ}$ ), acquisition time $4.5 \mathrm{~s}$ (or $0.7 \mathrm{~s}$ ), pulse delay $2 \mathrm{~s}$ (or $5 \mathrm{~s}$ ), number of scans 16 (or 64), and a pulse width of $5 \mu \mathrm{s}$ for ${ }^{19} \mathrm{~F}$ NMR.

\section{Reactions in autoclave}

Example of iodine transfer polymerization (ITP) of VDF performed in the presence of 1,1,2,2-tetrafluoro-3-iodopropane at $75^{\circ} \mathrm{C}$.

A 160-mL Hastelloy (HC-276) autoclave, equipped with inlet and outlet valves, a manometer and a rupture disc, was degassed and pressurized with 30 bar of nitrogen to check eventual leaks; then, a $20 \mathrm{~mm} \mathrm{Hg}$ vacuum was operated for $30 \mathrm{~min}$. Under vacuum, were transferred into the autoclave $0.43 \mathrm{~g}\left(2 \times 10^{-3} \mathrm{~mol}\right)$ of tert-butylperoxypivalate, $5.04 \mathrm{~g}(2 \mathrm{x}$ $10^{-2} \mathrm{~mol}$ ) of 1,1,2,2-tetrafluoro-3-iodopropane and $100.0 \mathrm{~g}$ of 1,1,1,3,3-pentafluorobutane. Then, by mean of double weighing, $19.50 \mathrm{~g}\left(30 \times 10^{-2} \mathrm{~mol}\right)$ of VDF were introduced in the mixture. Then, the autoclave was progressively heated to $75^{\circ} \mathrm{C}$. There was an exotherm of ca. 
$10{ }^{\circ} \mathrm{C}$, followed by an increase of pressure from 20 bar up to 26 bar and then a sharp drop of pressure until to 20 bar was noted. After reaction, the autoclave was placed in an ice bath for about 60 minutes and $3.90 \mathrm{~g}$ of unreacted VDF were progressively released (the conversion of VDF was $80 \%$, and the chain transfer constant (CTA) conversion was $33 \%$ ). After opening the autoclave, about $120.0 \mathrm{~g}$ of a brown liquid were obtained. After evaporation of 1,1,1,3,3pentafluorobutane, the sample was dissolved in dimethylformamide (DMF), which enabled solubilization of both low average number degree of polymerization ( $\overline{\mathrm{DP}}_{\mathrm{n}}$ ) (also soluble in acetone) and high $\overline{\mathrm{DP}}_{\mathrm{n}}$, and polymers produced were precipitated by adding water into the DMF solution. White powders were obtained in all cases and ${ }^{19} \mathrm{~F}$ NMR led to a $\overline{\mathrm{DP}}_{\mathrm{n}}$ value of 35. The sample was characterized by ${ }^{19} \mathrm{~F}$ and ${ }^{1} \mathrm{H}$ NMR spectroscopy.

The same procedure was used for the ITP reaction of VDF with perfluorohexyl iodide (supporting information).

NMR characteristics are reported in Tables 2 and 3.

Insert Table 2

Insert Table 3 


\section{RESULTS AND DISCUSSION}

\section{1-Introduction on ITP}

Iodine transfer polymerization (ITP) of vinylidene fluoride deals with the "degenerative transfer" as reversible addition fragmentation transfer (RAFT) ${ }^{24}$ or macromolecular design for interchange of xanthate ${ }^{25,26}$. This is an extension of the telomerization $^{1,27}$ taking into account the major difference that the macromolecular chains having undergone a transfer reaction may be involved in a further reaction.

As for the telomerization, ITP requires a chain transfer agent (CTA), and in that present case, an 1-iodofluoroalkane was chosen. Scheme 1 depicts the different steps of ITP of a $\mathrm{M}$ monomer.

\section{Insert Scheme 1}

The initiating radical, $\mathrm{A}^{\bullet}$, is generated by thermal decomposition of a conventional initiator, such as tert-butylperoxypivalate or 2,5-bis(tert-butylperoxide)-2,5-dimethylhexane, in step (a). Then, $A^{\bullet}$ radical reacts onto monomer (M) in step (b), followed by propagation of $M$ as shown in step (c). The exchange of iodine from the transfer agent, $R_{F}-I$, to the propagating radical, $\mathrm{P}_{n}{ }^{\circ}$, results in the formation of the polymeric alkyl iodide, $\mathrm{P}_{n}-\mathrm{I}$, and a new initiating radical, $\mathrm{R}^{\bullet}$ (step (d)). Large differences in the stability of the reactants and products involved in step (e) could result in shifting the equilibrium overwhelmingly to the right or to the left. Therefore, the ideal case is when the structure of $R_{F}$ closely resembles the structure of the propagating radical, resulting in a thermodynamically neutral transfer step. The exchange process described in step (e) is thermodynamically neutral, because $\mathrm{P}_{n}$ and $\mathrm{P}_{m}$ propagating chains are identical. Step (e) shows an equilibrium between dormant and living species which is crucial $^{1,3}$ for a pseudoliving behavior. As in any radical process, reaction of termination occurs, such as disproportionation and coupling of macroradicals (step f). But, to preserve the living or controlled behavior, the termination reaction ( $f$ ) must be negligible about the transfer ones (this condition is used for the other controlled radical polymerizations, such as ATRP, RAFT, or MADIX) and two key parameters must be taken into account:

i) the initiator amount must be as low as possible to avoid any presence of dormant (or dead) chains but in efficient amount to initiate that radical reaction. However, that amount depends upon the purity of the chain transfer agent. Actually, traces of iodine in the medium may allow an overconsumption of initiator and an inhibition time may occur ${ }^{28}$. 
ii) The CTA amount enables to control the molar masses of the produced polymers. In the ideal case of a total conversion of CTA, the theoretical number average degree of polymerization ( $\left.\overline{\mathrm{DP}}_{\mathrm{n}}\right)$ can be assessed from Equation (1) :

$$
\overline{D P_{n}}=\frac{\alpha_{V D F}[V D F]_{0}}{[C T A]_{0}}
$$

where $[\mathrm{VDF}]_{0},[\mathrm{CTA}]_{\mathrm{o}}$ and $\alpha_{\mathrm{VDF}}$ represent the monomer and CT A concentrations in feed and the VDF conversion, respectively.

The reactivity of CTA can be controlled by carrying out different reactions that make varying the theoretical (or targeted) $\overline{\mathrm{DP}}_{\mathrm{n}} s$ and to compare them with those obtained experimentally. A satisfactory agreement between these values enables one to confirm the good reactivity of the CTA.

\section{2-Results}

Iodine transfer polymerization of vinylidene fluoride was initiated by tert-butylperoxypivalate (TBPPI), in the presence of a iodofluorinated chain transfer agent $\left(\mathrm{C}_{6} \mathrm{~F}_{13} \mathrm{I}\right.$ and $\left.\mathrm{HC}_{2} \mathrm{~F}_{4} \mathrm{CH}_{2} \mathrm{I}\right)$ and in 1,1,1,3,3-pentafluorobutane at $75^{\circ} \mathrm{C}$ for $4 \mathrm{hrs}$. After reaction and elimination of both the solvent and the CTA under vacuum, PVDF-I was precipitated from water. Its experimental $\overline{\mathrm{DP}}_{\mathrm{n}}$ value was assessed from ${ }^{19} \mathrm{~F}$ and ${ }^{1} \mathrm{H}$ NMR spectroscopy.

\section{2-1. ITP of VDF with $\mathrm{C}_{\mathbf{6}} \mathrm{F}_{\mathbf{1 3}} \mathrm{I}$}

As expected, the ${ }^{19} \mathrm{~F}$ NMR spectrum (Figure 1) exhibits, beside the absence of the multiplet centered at $-60.0 \mathrm{ppm}$ attributed to $-\mathrm{CF}_{2} \mathrm{CF}_{2} \mathrm{I}$ of $\mathrm{C}_{6} \mathrm{~F}_{13} \mathrm{I}$ that has undergone a high field shift to $-112.0 \mathrm{ppm}$, the characteristic signals of $\mathrm{C}_{5} \mathrm{~F}_{11}$ end-group centered at -82.0 , $-124.0,-126.0$ and $-128.0 \mathrm{ppm}$ assigned to $\mathrm{CF}_{3}$ and the four $\mathrm{CF}_{2}$ groups, respectively ${ }^{29-31}$. The major signal centered at $-91.0 \mathrm{ppm}$ is attributed to difluoromethylene groups $-\mathrm{CH}_{2} \mathrm{CF}_{2}$ $\mathrm{CH}_{2} \mathrm{CF}_{2}-\mathrm{CH}_{2} \mathrm{CF}_{2}$ - (i.e. normal head-to-tail VDF-chaining).

\section{Insert Figure 1}


The presence of the triplet $\left({ }^{3} \mathrm{~J}_{\mathrm{FH}}=7.0 \mathrm{~Hz}\right)$ of triplets $\left({ }^{4} \mathrm{~J}_{\mathrm{FF}}=9.8 \mathrm{~Hz}\right)$ centered at -38.0 ppm evidences the expected $-\mathrm{CH}_{2} \mathrm{CF}_{2} \mathrm{I}$ end-group (e) while both signals at $-108.0 \mathrm{ppm}\left(\mathrm{e}^{\prime}\right)$ correspond to the difluoromethylene in $-\mathrm{CH}_{2} \mathrm{CF}_{2}-\mathrm{CF}_{2} \mathrm{CH}_{2} \mathrm{I}$ group ${ }^{19-23,29}$, arising from a reversed addition followed by a transfer step.

Indeed, Scheme 2 illustrates the different reactions that occur in ITP of VDF and enable to understand the defects of VDF chaining. Surprisingly, the ${ }^{19}$ F NMR spectrum (Figure 1) shows only traces of both multiplets centered at -113.0 and $-116.0 \mathrm{ppm}$ assigned to $-\mathrm{CH}_{2} \mathrm{CF}_{2}-\mathrm{CF}_{2} \mathrm{CH}_{2}-\mathrm{CH}_{2} \mathrm{CF}_{2}$ - reversed head-to-head addition, respectively, as usually observed in VDF-containing telomers ${ }^{20-22,29}$, oligomers ${ }^{19,21,23}$ or polymers ${ }^{23,32}$.

\section{Insert Scheme 2}

${ }^{1}$ H NMR spectrum of that same sample (Figure 2) confirms the statements above. Methylene groups located between two difluoromethylenes led to a quintet centered at about $3.0 \mathrm{ppm}$ while the signals centered at $3.3,3.6$ and $3.9 \mathrm{ppm}$ are attributed to methylene groups in $\mathrm{C}_{6} \mathrm{~F}_{13} \mathrm{CH}_{\underline{2}^{-}},-(\mathrm{VDF})_{\mathrm{n}} \mathrm{CH}_{2} \mathrm{CF}_{2} \mathrm{I}$, and $-\mathrm{CF}_{2} \mathrm{C}_{2} \mathrm{H}^{29,31,33}$, respectively.

\section{Insert Figure 2}

As expected, $-\mathrm{CF}_{2} \mathrm{C}_{2}-\mathrm{C}_{2}{ }_{2} \mathrm{CF}_{2}$ - reverse tail-to-tail additions are noted by the presence of a broad signal centered at $2.5 \mathrm{ppm}^{19-23,32,33}$, although their integrals are small for low $\overline{\mathrm{DP}}_{\mathbf{n}}$ and increase for higher $\overline{\mathrm{DP}}_{\mathrm{n}}$. Interestingly, the absence of triplets centered at 1.2 and $1.8 \mathrm{ppm}$ characteristic of methyl end-groups in $\mathrm{CH}_{3} \mathrm{CH}_{2} \mathrm{CF}_{2^{-}}$and $\mathrm{C}_{3} \mathrm{CF}_{2} \mathrm{CH}_{2^{-}}$groups ${ }^{20,23}$, respectively, evidences the absence of the direct initiation of ${ }^{\circ} \mathrm{CH}_{3}$ (arising from $\left(\mathrm{CH}_{3}\right)_{3} \mathrm{CO}^{\bullet}$ generated by tert-butylperoxypivalate) and $\left(\mathrm{CH}_{3}\right)_{3} \mathrm{C}^{\bullet}$ onto VDF as previously observed ${ }^{23}$.

$\overline{\mathrm{DP}}_{\mathrm{n}}$ values can be assessed from ${ }^{1} \mathrm{H}$ and ${ }^{19} \mathrm{~F}$ NMR spectra :

i) from ${ }^{1} \mathrm{H}$ NMR, taking into account the integrals of the signal attributed to methylene groups $\left(\int \mathrm{CH}_{2}\right)$ in PVDF about those of $\underline{\mathrm{CH}}_{2}$ adjacent to $\mathrm{C}_{6} \mathrm{~F}_{13}$ end-groups, as follows :

$$
\overline{D P n}=\frac{\int \mathrm{CH}_{2}^{2.5 p p m}+\int \mathrm{CH}_{2}{ }^{3.0 p p m}+\int \mathrm{CH}_{2}{ }^{3.3 p p m}+\int \mathrm{CH}_{2}{ }^{3.6 p p m}+\int \mathrm{CH}_{2}^{3.9 p p m}}{\int \mathrm{CH}_{2}{ }^{3.3 p p m}}
$$


ii) from ${ }^{19} \mathrm{~F}$ NMR spectrum (Figure 1) taking into account the integrals of signals of $\mathrm{CF}_{2}$ assigned to PVDF centered at $-91.0 \mathrm{ppm},-38.0 \mathrm{ppm}$ and $-108.0 \mathrm{ppm}$ about that of $\mathrm{CF}_{3}$ end-group centered at $-82.0 \mathrm{ppm}$, as follows :

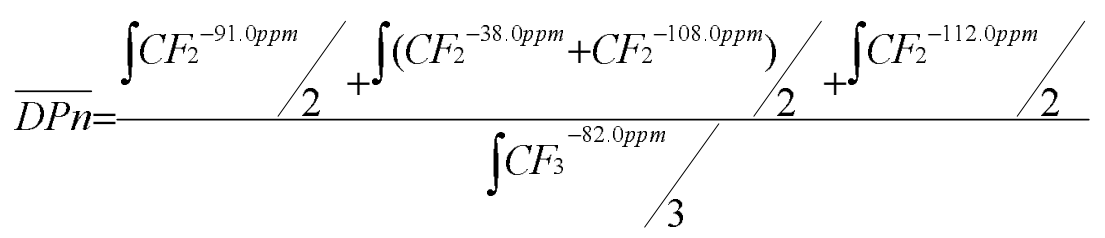

Table 4 represents the experimental reactant molar ratios, the targeted and experimental $\overline{\mathrm{DP}}_{\mathrm{n}}$ values and the theoretical and experimental functionalities (in iodine).

Indeed, the obtained values of $\overline{\mathrm{DP}}_{\mathrm{n}}$ are slightly lower than those expected. This difference can be explained by a non-total conversion of VDF (in the 70-90\% range).

Actually, in the course of the propagation step of ITP, the reactivity of $\operatorname{mmm} \mathrm{CH}_{2} \mathrm{CF}_{2}{ }^{\bullet}$ macroradical onto VDF can lead either to a normal or reverse addition (Scheme 2). Transfer steps of the produced macroradicals hence yield mum $\mathrm{CH}_{2} \mathrm{CF}_{2}-\mathrm{CH}_{2} \mathrm{CF}_{2} \mathrm{I}$ and $\operatorname{mm} \mathrm{CH}_{2} \mathrm{CF}_{2}$ $\mathrm{CF}_{2} \mathrm{CH}_{2} \mathrm{I}$, for which the characteristic signals of both $\mathrm{CF}_{2}$ end-groups appear at -38.0 and $-108.0 \mathrm{ppm}$, respectively.

Therefore, the functionalities in $-\mathrm{CF}_{2} \mathrm{I}$ and $-\mathrm{CF}_{2} \mathrm{CH}_{2} \mathrm{I}$ can be assessed from NMR by following equations (4) and (5) :

$$
\text { functionality }^{-C F_{2}-I}=\frac{\int C F_{2}-I^{-38.0 p p m} / / 2}{\int C F_{3}^{-82.0 p p m} / / 3}
$$

Equations (4-a) and (4-b)enable one to determine the functionalities in $-\mathrm{CF}_{2} \mathrm{I}$ and $-\mathrm{CF}_{2} \mathrm{CH}_{2} \mathrm{I}$ by ${ }^{19} \mathrm{~F}$ NMR, respectively.

$$
\text { functionality }^{-\mathrm{CF}_{2} \mathrm{CH}_{2}-1}=\frac{\int-\mathrm{CF}_{2}^{-108.0 p p m}}{\int \mathrm{CF}_{3}^{-82.0 p p m} / 2}
$$

The experimental values of such functionalities (Table 4) can be compared to those determined by ${ }^{1} \mathrm{H}$ NMR taking into account the characteristic signals of $-\mathrm{CF}_{2} \mathrm{C}_{2} \underline{2}$, $-\mathrm{C}_{2} \mathrm{CF}_{2} \mathrm{I}$ and $\mathrm{C}_{6} \mathrm{~F}_{13} \underline{\mathrm{C}}_{2}$ (VDF) $)_{\mathrm{n}} \mathrm{I}$ noted at 3.9, 3.7 and 3.3. ppm, respectively, as follows : 


$$
\text { functionality }^{-C F_{2}-I}=\frac{\int-\mathrm{CH}_{2}-C F_{2}-I^{3.7 p p m} / 2}{\int R F-C \underline{H_{2}}-C F_{3}-(V D F)_{n}-I^{3.3 p p m} / 2}
$$$$
\text { functionality }^{-\mathrm{CF}_{2} \mathrm{CH}_{2}-\mathrm{I}}=\frac{\int-\mathrm{CF}_{2}-\mathrm{CH}_{2}-I^{3.9 p p m}}{\int R F-\mathrm{CH}_{2}-C F_{2}-(V D F)_{n}-I^{3.3 p p m}}
$$

Equations (5-a) and (5-b) also allow one to assess the functionalities in $-\mathrm{CF}_{2} \mathrm{I}$ and $-\mathrm{CF}_{2} \mathrm{CH}_{2} \mathrm{I}$ by ${ }^{1} \mathrm{H}$ NMR, respectively.

Table 4 also lists the functionalities of PVDF-I in $-\mathrm{CF}_{2} \mathrm{I}$ and $-\mathrm{CF}_{2} \mathrm{CH}_{2} \mathrm{I}$ and shows a good agreement of these values calculated from ${ }^{19} \mathrm{~F}$ or ${ }^{1} \mathrm{H}$ NMR spectroscopy. This table also shows that $-\mathrm{CF}_{2} \mathrm{I}$ functionality regularly decreases for higher targeted $\overline{\mathrm{DP}}_{\mathrm{n}}$. Indeed, this drop of functionality arises from the reversed addition of the macroradical onto VDF in the propagation step. The literature reports various defects of chaining, usually ranging between 6 and $9 \%$ for $\mathrm{PVDF}^{32,34,35}$ or for oligo(VDF) ${ }^{19,21,23}$ and $5-10 \%$ for VDF telomers ${ }^{1,20,22,29,31}$, although a recent work reports a value of $2.5 \%$ from fractionated $\mathrm{CF}_{3}(\mathrm{VDF})_{\mathrm{n}} \mathrm{I}$ telomers ${ }^{33}$.

\section{Insert Table 4}

Equation (6) supplies the theoretical functionality linking the content of chains that do not undergo any inversion $(\psi)$ and the n number of VDF units, taking into account that the addition of $\mathrm{C}_{6} \mathrm{~F}_{13}{ }^{\bullet}$ onto VDF is regioselective and always occurs as a normal addition ${ }^{29,31,33}$ hence showing a " $n-1$ " value in equation (6) :

$$
\text { Theoretical functionality in } \mathrm{CF}_{2}-\mathrm{I}=(\psi)^{(n-1)}
$$

By varying $\psi$ value, the rate of reverse addition can be determined for each addition onto a further VDF (Table 4). The obtained value is close to $95 \%$ (this value gives the best fitting with the experimental values). Indeed, for a PVDF-I of $\overline{\mathrm{DP}}_{6}, 77 \%$ of $-\mathrm{CF}_{2} \mathrm{I}$ end-groups has been observed experimentally, while for PVDF-I of $\overline{\mathrm{DP}}_{13},-\mathrm{CF}_{2} \mathrm{I}$ theoretical (from Equation (6)) and experimental contents are identical (54\%). These values show that the reverse addition of VDF is not disturbed by ITP. Hence, mechanism of ITP does not prevent from limiting the inversions. 
Then, the fractionation of produced PVDF-I $\left(\overline{\mathrm{DP}}_{25}\right)$ was carried out in acetone then in methanol to separate higher from lower molecular weight-PVDF-I (Table 5). Such a procedure enabled us to assess the distribution of oligomers bearing $-\mathrm{CF}_{2} \mathrm{I}$ end-group.

Interestingly, low $\overline{\mathrm{DP}}_{\mathrm{n}}$ fractions (i.e., F1 and F2) contain PVDF-I bearing $-\mathrm{CF}_{2} \mathrm{CH}_{2} \mathrm{I}$ end-group exclusively as evidenced by ${ }^{19} \mathrm{~F}$ and ${ }^{1} \mathrm{H}$ NMR (Table 5). This observation can be explained by two features :

i) $-\mathrm{CH}_{2} \mathrm{I}$ end group is totally unreactive and can not lead to any transfer reaction thus stopping the polymerization;

ii) $-\mathrm{CH}_{2} \mathrm{I}$ is far less reactive than $-\mathrm{CF}_{2} \mathrm{I}$; hence the presence of $-\mathrm{CF}_{2} \mathrm{I}$ end group in the medium still enables further transfer reactions. For a better understanding of that reaction, it was worth attempting an ITP of VDF with a chain transfer agent bearing a $-\mathrm{CF}_{2} \mathrm{CH}_{2} \mathrm{I}$ end group, described below.

\section{Insert Table 5}

\section{2-2 ITP of VDF in the presence of $\mathrm{HC}_{2} \mathrm{~F}_{4} \mathrm{CH}_{2} \mathrm{I}$}

The structure of $\mathrm{HCF}_{2}\left(\mathrm{CF}_{2} \mathrm{CH}_{2}\right) \mathrm{I}$ exhibits a VDF unit adjacent to an iodine end-group as frequently involved in controlled radical polymerization ${ }^{1-3}$.

A reaction was carried out as above starting from the following initial concentration molar ratios : $[\mathrm{VDF}]_{0}:[\mathrm{CTA}]_{0}:[\mathrm{TBPPI}]_{0}=100.0: 6.6: 0.6$. After reaction, a sample was taken off from the total product mixture and was characterized by NMR. The remaining solution was evaporated, precipitated from water and dried under vacuum at $60{ }^{\circ} \mathrm{C}$ for $24 \mathrm{hrs}$. The obtained polymer was also characterized by NMR. In contrast to the absence of $\mathrm{C}_{6} \mathrm{~F}_{13} \mathrm{I}$ observed in the case above, the presence of unreacted $\mathrm{HC}_{2} \mathrm{~F}_{4} \mathrm{CH}_{2} \mathrm{I}$ was noted by means of ${ }^{1} \mathrm{H}$ (presence of a triplet of triplets and of a quintet centered at 6.5 and $3.6 \mathrm{ppm}$, respectively) and

${ }^{19} \mathrm{~F}$ NMR (presence of a triplet $\left({ }^{3} \mathrm{~J}_{\mathrm{FF}}=17.8 \mathrm{~Hz}\right.$ ) of quartets $\left({ }^{3} \mathrm{~J}_{\mathrm{HF}}=3.4 \mathrm{~Hz}\right.$ ) and of a doublet $\left({ }^{2} \mathrm{~J}_{\mathrm{HF}}=49.6 \mathrm{~Hz}\right)$ of triplets $\left({ }^{3} \mathrm{~J}_{\mathrm{HF}}=4.0 \mathrm{~Hz}\right)$ centered at -112.0 and $-136.0 \mathrm{ppm}$, assigned to $-\mathrm{CF}_{2} \mathrm{CH}_{2} \mathrm{I}$ and $\mathrm{HCF}_{2}-$, respectively).

Figure 3 exhibits the ${ }^{19} \mathrm{~F}$ NMR spectrum of the sample produced from ITP of VDF with $\mathrm{HC}_{2} \mathrm{~F}_{4} \mathrm{CH}_{2} \mathrm{I}$ for which the characteristic signal (assigned to $\mathrm{HCF}_{2}$ - end-group) of the unreacted CTA is located at $-136.0 \mathrm{ppm}$. After ITP of VDF, the signal of $\mathrm{HCF}_{2}-$ group underwent a slight high field shift from $-136.0 \mathrm{ppm}$ (unreacted CTA) to $-138.0 \mathrm{ppm}$. In 
addition, this spectrum shows that the chemical shifts assigned to $\mathrm{CF}_{2}$ groups of incorporated VDF were similar to those of PVDF-I (Figure 3), just like the other methylene in the CTA.

\section{Insert Figure 3}

Thus, $\overline{\mathrm{DP}}_{\mathrm{n}}$ value was assessed from the integrals of the characteristic signals about that of $\mathrm{HCF}_{2}-$ end-group, as follows (eq. 7) :

$$
\overline{D P n}=\frac{\int C F_{2}^{-91.0 p p m}+\int C F_{2}^{-95.0 p p m}+\int\left(C F_{2}^{-38.0 p p m}+C F_{2}^{-108.0 p p m}\right)+\int C F_{2}^{-112 p p m}+\int C F_{2}^{-115 p p m}}{\int C F_{2}^{-138.0 p p m}}
$$

Figure 3 shows the absence of the signal located at $-38.0 \mathrm{ppm}$ assigned to $-\mathrm{CF}_{2} \mathrm{CH}_{2} \mathrm{I}$.

${ }^{1} \mathrm{H}$ NMR spectrum (Figure 4) also exhibits the characteristic signal centered at $6.5 \mathrm{ppm}$ attribuate to $\mathrm{HCF}_{2} \mathrm{CF}_{2-}$, while the other signals assigned to the methylene groups are similar to those noted in the ${ }^{1} \mathrm{H}$ NMR spectra of the above $\mathrm{C}_{6} \mathrm{~F}_{13}$-PVDF-I. The signal centered at $6.5 \mathrm{ppm}$ shows a complex shape, because there is an overlapping of two triplets of triplets which have different coupling constants: $\mathrm{HCF}_{2} \mathrm{CF}_{2}$ - assigned from chain transfer agent, which appears at $6.5 \mathrm{ppm}$ and $\mathrm{HCF}_{2} \mathrm{CH}_{2}$ - from transfer reaction, which appears at $6.3 \mathrm{ppm}$, as expected. However, the defects of chaining (tail-to-tail adducts evidenced by the broad multiplet centered at $2.6 \mathrm{ppm}$ ) are in a higher amount in these $\mathrm{HC}_{2} \mathrm{~F}_{4} \mathrm{CH}_{2}$-PVDF-I polymers (Figure 4). The presence of signals centered at $1.0,1.2,1.3$ and $1.8 \mathrm{ppm}$ shows the direct initiation of $\mathrm{CH}_{3}{ }^{\bullet}$ and $\mathrm{C}\left(\mathrm{CH}_{3}\right)^{\bullet}$ (generated than the decomposition of tert-butylperoxy pivalate) ${ }^{23}$ onto VDF. This initiator decomposition generates two radicals: $\left(\mathrm{CH}_{3}\right)_{3} \mathrm{C}^{\bullet}$ and tert-butoxyradicals $\left(\left(\mathrm{CH}_{3}\right)_{3} \mathrm{CO}^{\bullet}\right.$ that rearrange to produce $\mathrm{CH}_{3}{ }^{\circ}$ radical and acetone (Scheme 3).

\section{Insert Scheme 3}

As shown earlier ${ }^{23}, \mathrm{CH}_{3}{ }^{\circ}$ and $\left(\mathrm{CH}_{3}\right)_{3} \mathrm{C}^{\bullet}$ radicals can be added onto $\mathrm{CH}_{2}$ or $\mathrm{CF}_{2}$ sites of VDF. Thus, these different additions leading to four structures : $\left(\mathrm{C}_{3}\right)_{3} \mathrm{C}-\mathrm{CH}_{2}-\mathrm{CF}_{2^{-}}, \mathrm{CH}_{3}-\mathrm{CH}_{2}-\mathrm{CF}_{2^{-}}$, $\left(\mathrm{C}_{3}\right)_{3} \mathrm{C}-\mathrm{CF}_{2}-\mathrm{CH}_{2}-$ and $\mathrm{C}_{3}-\mathrm{CF}_{2}-\mathrm{CH}_{2}$ - end-groups evidenced by signals ( $\left.{ }^{1} \mathrm{H} \mathrm{NMR}\right)$ at $1.0,1.2$, 1.3 and $1.8 \mathrm{ppm}$, respectively (Figure 4). The structure $\mathrm{CH}_{3}-\mathrm{CH}_{2}-\mathrm{CF}_{2}-$ is confirmed by the signal centered at $-95.7 \mathrm{ppm}$ in ${ }^{19} \mathrm{~F}$ NMR spectrum, while the other signals $\left(\left(\mathrm{CH}_{3}\right)_{3} \mathrm{C}-\mathrm{CH}_{2}-\mathrm{CF}_{2}-\right.$ 
, $\mathrm{CH}_{3}-\mathrm{CF}_{2}-\mathrm{CH}_{2}-$ and $\left.\left(\mathrm{CH}_{3}\right)_{3} \mathrm{C}-\mathrm{CF}_{2}-\mathrm{CH}_{2}-\right)$ are overlapping with other signals in ${ }^{19} \mathrm{~F}$ NMR spectrum.

\section{Insert Figure 4}

As in equation $7, \overline{\mathrm{DP}}_{\mathrm{n}}$ values were assessed from the integrals of all methylene groups, taking into account that of "labeled" $\underline{H C F}_{2-}, \mathrm{C}_{\underline{3}}-\mathrm{CF}_{2}-\mathrm{CH}_{2}-,\left(\mathrm{C}_{3}\right)_{3} \mathrm{C}-\mathrm{CH}_{2}-\mathrm{CF}_{2^{-}}$, $\mathrm{CH}_{3}-\mathrm{CH}_{2}-\mathrm{CF}_{2}-$ and $\left(\mathrm{C}_{3}\right)_{3} \mathrm{C}-\mathrm{CF}_{2}-\mathrm{CH}_{2}$ - end-groups (Eq. 8) :

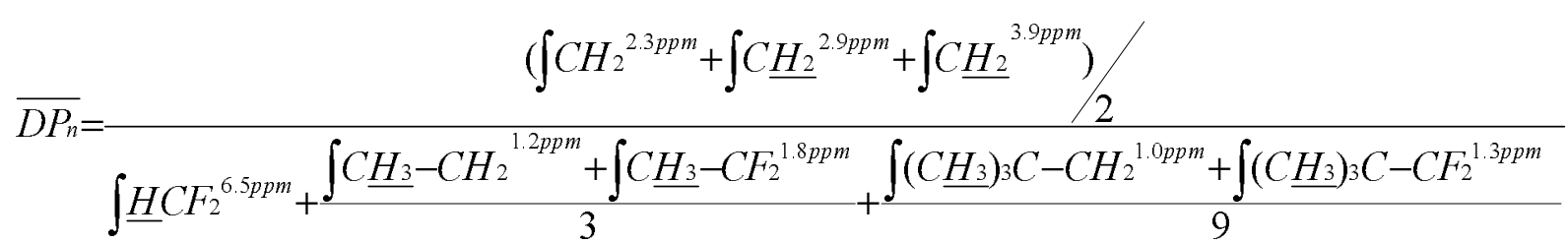

The experiments were carried out at 75 and $135{ }^{\circ} \mathrm{C}$, initiated by tertbutylperoxypivalate (TBPPI) and 2,5-bis(tert-butylperoxide)-2,5-dimethylhexane (DHBP), respectively. The targeted and experimental values of $\overline{\mathrm{DP}}_{\mathrm{n}}$ for ITP reaction performed with various concentrations of $\mathrm{HCF}_{2}\left(\mathrm{CF}_{2} \mathrm{CH}_{2}\right) \mathrm{I}$ are listed in Table 6. A major difference is noted between targeted and obtained $\overline{\mathrm{DP}}_{\mathrm{n}}$ values. This discrepency arises from the low CTA conversion (i.e., $33 \%$ was reacted) with respect to the low reactivity of this CTA.

\section{Insert Table 6}

A major difference is noted between the $\overline{\mathrm{DP}}_{\mathrm{n}}$ values obtained from ${ }^{1} \mathrm{H}$ and ${ }^{19} \mathrm{~F}$ NMR. This difference can be explained by direct initiation of (TBPPI or DHBP) initiator. ${ }^{19} \mathrm{~F}$ NMR does not allow taking into account the chains resulting from direct initiation. The interval of confidence of $\overline{\mathrm{DP}}_{\mathbf{n}}$ values obtained from ${ }^{19} \mathrm{~F}$ NMR is about $10-15 \%$.

${ }^{1} \mathrm{H}$ NMR, enables one to quantify the chain percentage $(\varepsilon)$ resulting from direct initiation. Thus, the rate of direct initiation was evaluated from ${ }^{1} \mathrm{H}$ NMR, by equation 9. The percentage of the CTA end-chain is shown by the $\mathrm{HCF}_{2} \mathrm{CF}_{2}$ - signal which appears at $6.5 \mathrm{ppm}$. This is possible since it is assumed that in these conditions, $\mathrm{CF}_{3} \mathrm{CH}_{2} \mathrm{CF}_{2} \mathrm{CH}_{3}$ does not lead to any transfer, hence avoiding the formation of characteristic $-\mathrm{C}_{2} \mathrm{CF}_{2}-\mathrm{H}$ end-group which appears as a triplet to triplets centered at $6.3 \mathrm{ppm}^{20,21,23}$. This is confirmed by the absence of 
the characteristic doublet of multiplets centered at $-114.8 \mathrm{ppm}{ }^{20,21,23}$ in the ${ }^{19} \mathrm{~F}$ NMR spectrum.

$$
\varepsilon=\frac{\frac{\int\left(\mathrm{CH}_{3}\right)_{3} \mathrm{C}-\mathrm{CH}_{2}{ }^{1.0 p p m}+\int\left(\mathrm{CH}_{3}\right)_{3} \mathrm{C}-\mathrm{CF}_{2}{ }^{1.3 p p m}}{9}+\frac{\int \mathrm{CH}_{3}-\mathrm{CH}_{2}^{1.2 p p m}+\int \mathrm{CH}_{3}-\mathrm{CF}_{2}^{1.8 p p m}}{3}}{\frac{\int\left(\mathrm{CH}_{3}\right)_{3} \mathrm{C}-\mathrm{CH}_{2}{ }^{1.0 p p m}+\int(\mathrm{CH})_{3} \mathrm{C}-\mathrm{CF}_{2}^{1.3 p p m}}{9}+\frac{\int \underline{\mathrm{H}}_{3}-\mathrm{CH}_{2}^{1.2 p p m}+\int \mathrm{CH}_{3}-\mathrm{CF}_{2}^{1.8 p p m}}{3}+\int \underline{\mathrm{HCF}}{ }_{2}^{6.5 p p m}}
$$

$\varepsilon$ Values are summarized in Table 6 and show the low efficiency of $\mathrm{HC}_{2} \mathrm{~F}_{4} \mathrm{CH}_{2} \mathrm{I}$ in contrast to that of $\mathrm{C}_{6} \mathrm{~F}_{13} \mathrm{I}$. Hence, it can not lead to a good control of molar masses at $75{ }^{\circ} \mathrm{C}$. This statement can be explained by the dissociation energy of $-\mathrm{CH}_{2}$-I bond which is stronger than that of $-\mathrm{CF}_{2}$-I (ca. $45 \mathrm{~kJ} \cdot \mathrm{mol}^{-1}{ }^{1}$ ). To make lower the stability of $-\mathrm{CH}_{2}$-I bond and hence to improve the transfer step, ITP of VDF with $\mathrm{HC}_{2} \mathrm{~F}_{4} \mathrm{CH}_{2} \mathrm{I}$ was carried out at $135{ }^{\circ} \mathrm{C}$ (Table 6). The CTA conversion increased $(66 \%)$ while the control of the $\overline{\mathrm{DP}}_{\mathrm{n}}$ was slightly improved. However, $\mathrm{HC}_{2} \mathrm{~F}_{4} \mathrm{CH}_{2} \mathrm{I}$ does not lead to any good control of the molar masses. Deeper experiments are under progress, especially the kinetics of ITP of VDF, to check whether this radical polymerization is controlled or pseudoliving.

\section{CONCLUSION}

Two fluoroiodinated chain transfer agents involved in the iodine transfer polymerization (ITP) of vinylidene fluoride have shown different behaviors in transfer, leading to different consequences in $\mathrm{ITP}^{37}$. $\mathrm{C}_{6} \mathrm{~F}_{13} \mathrm{I}$ exhibits high efficiency and reactivity, thus inducing a good control of average degree of polymer in number $\left(\overline{\mathrm{DP}}_{\mathrm{n}}\right)$ and a few defects of VDF chaining. Such a reaction is close to a pseudoliving polymerization, but to check that observation a deeper study is nesessary. In contrast, $\mathrm{HC}_{2} \mathrm{~F}_{4} \mathrm{CH}_{2} \mathrm{I}$ behaves differently in similar conditions and leads to PVDF-I polymers containing higher defects of VDF chaining and having uncontrolled $\overline{\mathrm{DP}}_{\mathrm{n}}$ (experimental values were almost twice higher than those of the targeted ones). At higher temperatures, greater CTA conversions were noted while a slightly better control of $\overline{\mathrm{DP}}_{\mathrm{n}}$ was achieved. The microstructure of resulting PVDF-I leads to the following conclusions:

i) ITP of VDF involving $\mathrm{C}_{6} \mathrm{~F}_{13} \mathrm{I}$ produced two structures: $\mathrm{C}_{6} \mathrm{~F}_{13}-(\mathrm{VDF})_{\mathrm{n}}-\mathrm{CH}_{2}-\mathrm{CF}_{2}-\mathrm{I}$ and

$$
\mathrm{C}_{6} \mathrm{~F}_{13}-(\mathrm{VDF})_{\mathrm{n}}-\mathrm{CF}_{2}-\mathrm{CH}_{2}-\mathrm{I} \text {; }
$$


ii) When the macroradical terminated by $-\mathrm{CH}_{2} \mathrm{CF}_{2}{ }^{\circ}$ reacts onto $\mathrm{CF}_{2}$ site of VDF, the generated $-\mathrm{CH}_{2}-\mathrm{CF}_{2}-\mathrm{CF}_{2}-\mathrm{CH}_{2}{ }^{\bullet}$ (head to head addition) radical undergoes a transfer which is not able to reinitiate $\left(-\mathrm{CF}_{2}-\mathrm{CH}_{2}-\mathrm{I}\right)$, hence lading to dormant species which stoped the reaction.

However, further investigations are required to understand ITP of VDF (i.e., to check the pseudoliving character of ITP by establishing the molar masses versus VDF conversion linear relationship) and to study the kinetics of that polymerization. Hence, it is worth assessing the transfer constants of $\mathrm{C}_{6} \mathrm{~F}_{13} \mathrm{I}, \mathrm{HC}_{2} \mathrm{~F}_{4} \mathrm{CH}_{2} \mathrm{I}$ and also $\mathrm{C}_{6} \mathrm{~F}_{13} \mathrm{CH}_{2} \mathrm{CF}_{2} \mathrm{I}$ and to study the "molar masses -VDF conversion" relationships in each case, under investigation.

\section{ACKNOWLEDGMENTS}

The authors thank Solvay S.A. (Brussells, Belgium and Tavaux, France) for the free samples of vinylidene fluoride and 1,1,1,3,3-pentafluorobutane and La Chalonnaise des Peroxydes, Châlons sur Marne, France, for supplying tert-butyl peroxypivalate.

\section{SUPPORTING INFORMATION}

Supporting Information Available: ${ }^{19} \mathrm{~F}$ NMR spectra of $\mathrm{C}_{6} \mathrm{~F}_{13}-\mathrm{I}, \mathrm{C}_{6} \mathrm{~F}_{13}-\mathrm{CH}_{2}-\mathrm{CF}_{2}-\mathrm{I}$, $\mathrm{HC}_{2} \mathrm{~F}_{4} \mathrm{CH}_{2} \mathrm{I}$ and of sample produced by ITP of VDF with $\mathrm{HC}_{2} \mathrm{~F}_{4} \mathrm{CH}_{2} \mathrm{I}$. This material is available free of charge via the Internet at http://pubs.acs.org. 


\section{REFERENCES AND NOTES}

(1) Ameduri, B.; Boutevin, B. Well-Architectured Fluoropolymers: Fluorotelomers, telechelics, alternating, block and graft copolymers; Elsevier, Amsterdam, 2004.

(2) Matyjaszewski, K.; Xia J. Chem. Rev. 2001, 101, 2921-3089.

(3) Matyjaszewski, K. Controlled /living radical polymerization : Progress in ATRP, NMP and RAFT, ACS Symp. Ser. (Amer. Chem. Soc) 2000, 768, Washington D.C. (USA).

(4) Lacroix-Desmazes, P.; Severac, R.; Boutevin, B.; Bodart, V.; Kurowski, V. World Patent WO2004094356 04.11.2004 (assigned to Solvay).

(5) Tatemoto, M. Proceedings of the "First Regular Meeting of Soviet-Japanese Fluorine Chemists" Conference, Tokyo, Feb. 1979.

(6) Tatemoto, M.; Tomoda, M.; Ueda, Y. Ger. Patent DE 29,401,35 (assigned to Daikin) 1980 (Chem. Abst. 93:27580).

(7) a) Yagi, T.; Tsuda, N.; Noguchi, T.; Sakaguchi, K.; Tanaka, Y.; Tatemoto, M. Eur. Pat. Appl. 0,422,644 A2, (assigned to Daikin) 11.10.1990; b) Tatemoto, M. Eur. Pat. Appl. 399,543, (assigned to Daikin). 28.11.1990.

(8) Yutani, Y.; Tatemoto, M.; Eur. Patent Appl. 0489370 Al (assigned to Daikin) 1991.

(9) Carlson, D.P. Eur. Pat. Appl. 0,444,700 A2, and US Pat 5,284,920 (assigned to E.I. DuPont de Nemours and Co.) 01.03.1991 and 08.02.1994.

(10) Hung, M.H. US Patent 5231154 (assigned to DuPont) 27.07.1993.

(11) Arcella, V. ; Brinati, G.; Albano, M.; Tortelli, V. Eur. Pat. Appl. 0,661,312 Al (assigned to Ausimont S.p.A.) 05.07.1995.

(12) Arcella, V.; Brinati, G.; Albano, M.; Tortelli, V. Eur. Pat. Appl. 0,683,186 Al (assigned to Ausimont S.p.A.) 09.05.1995.

(13) Gayer, U.; Schuh, T.; Arcella, V.; Albano, M. Eur. Pat. Appl. EP1,231,239 Al (assigned to Ausimont S.p.A.) 14.08.2002.

(14) a) Tatemoto, M. Iodine Transfer Polymerization; in Salamone J.C., Ed.; Polymeric Materials Encyclopedia, CRC Press, Boca Raton, USA 1996, 5, 3847-3859; b) Tatemoto M., Int. Polym. Sci. Techno. 1985, 12, 85-97.

(15) Tedder, J. M.; Walton, J. C. Adv. Free-Radical Chem.; London 1980, 6, 155-184.

(16) Fossey, J.; Lefort, D. ; Sorba, J. Free Radical in Organic Chemistry; Wiley, New York, 1995.

(17) Dolbier, W. R. Topics Curr. Chem. 1997, 192, 97-164. 
(18) Apsey, G.C.; Chambers, R.D.; Salisbury, M.J.; Moggi, G. J. Fluorine Chem. 1988, 40, 261-282.

(19) Russo, S.; Behari, K.; Chengi, S.; Pianca, M.; Barchiesi, E.; Moggi, G. Polymer 1993, $34,4777-4788$.

(20) Duc, M.; Améduri, B; Boutevin, B; Kharroubi, M.; Sage, J.M. Macromol. Chem. Phys. 1998, 199, 1271-1288.

(21) Pianca, M.; Barchiesi, E.; Esposto, G.; Radice, S. J. Fluorine Chem. 1999, 95, 71-84.

(22) Duc, M.; Ameduri, B.; Boutevin, B. J. Fluorine Chem. 2001, 112; 3-12.

(23) Guiot J.; Ameduri B.; Boutevin, B. Macromolecules 2002, 35, 8694-8707.

(24) Rizzardo, E.; Chiefari, J.; Mayadunne, R.T.A.; Moad, G.; Thang, S.H.; Synthesis of defined polymers by reversible addition-fragmentation chain transfer: the RAFT process, ACS Symp. Ser. 2000, 768, 278-286.

(25) Charmot, D.; Corpart, P.; Adam, H.; Zard, S.Z.; Biadatti, T.: Bouhadir, G. Macromol. Symp. 2000, 150, 23-31

(26) Destarac, M.; Bzducha, W.; Taton; D., Gauthier-Gillaizeau, I.; Zard, S.Z.; Macromol. Rapid Commun. 2002, 23, 1049-1054.

(27) Boutevin, B.; J. Polym. Sci., Part A, Polym. Chem. 2000, 38 (18), 3235-3243.

(28) Lacroix-Desmazes, P; Severac, R. ; Boutevin, B. Macromolecules 2005, 38 (15), 62996309.

(29) Balague, J.; Ameduri, B.; Boutevin, B.; Caporiccio, G. J. Fluorine Chem. 1995, 70, 215-223.

(30) Nouiri, M.; Ameduri, B.; Boutevin B.; J. Fluorine Chem. 1995, 74, 191-197.

(31) Balague, J.; Ameduri, B.; Boutevin, B.; Caporiccio, G. J. Fluorine Chem. 2000, 102, 253-268.

(32) Seilers, D. A. PVDF in the chemical process industry, in J. Scheirs, Ed., Modern Fluoropolymers, J. Wiley and Sons, New York, 1997, chapter 25, 487-506.

(33) Ameduri, B.; Ladaviere, C.; Delolme, F.; Boutevin B. Macromolecules 2004, 37, 76027609 .

(34) Chambers, R.D.; Hutchinson, J.; Mobbs, R.H.; Musgrave, W.K.R. Tetrahedron 1964, 20, 497-506.

(35) Dohany, R. E.; Dukert, A.A.; Preston, S.S. Copolymers of vinylidene fluoride; in Kirk R.

E., Othmer D. F., Encycl. Polym. Sci. Technol. 1989, 17, 532-547.

(36) Matyjaszewski, K.; Spanswick, J.; Material Today, March 2005, 26-33. 


\section{Scheme Captions}

Scheme 1. Elementary steps of Iodine Transfer Polymerization of M monomer

Scheme 2. Different reactions that occur in Iodine Transfer Polymerization of vinylidene fluoride.

Scheme 3. Decomposition of Tert-butylperoxypivalate, formation of the radicals and their addition onto vinylidene fluoride ${ }^{23}$. 
decomposition of (A2) initiator

$\mathrm{A}_{2} \longrightarrow \mathrm{A}^{\circ}$

(a)

initiation :

$\mathrm{A}^{\circ}$ $\mathrm{nM}$

$\mathrm{P}_{\mathrm{n}}{ }^{\circ}$

(b)

chain transfer :

$\left(\begin{array}{c}\mathrm{P}_{\mathrm{n}}^{\circ} \\ \mathrm{M}\end{array}\right)+\mathrm{I}-\mathrm{R} \rightleftharpoons \mathrm{P}_{\mathrm{n}}-\mathrm{I}+\mathrm{R}^{\circ}(\mathrm{c})$

propagation :

$\mathrm{R}^{\circ}$

$\mathrm{nM} \longrightarrow \mathrm{P}_{\mathrm{n}}{ }^{\mathrm{O}}$

(d)

equilibrium between dormant and living species :

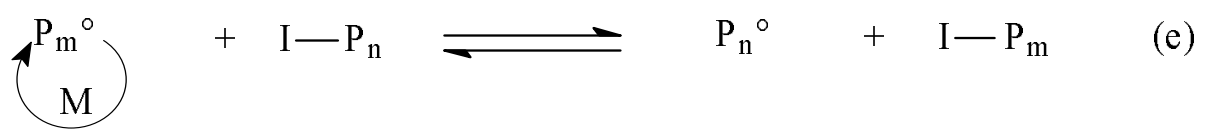

termination :

$\mathrm{P}_{\mathrm{n}}{ }^{\circ}+\mathrm{P}_{\mathrm{m}}{ }^{\circ} \longrightarrow$ dead chain

Scheme 1. Elementary steps of Iodine Transfer Polymerization of M monomer 


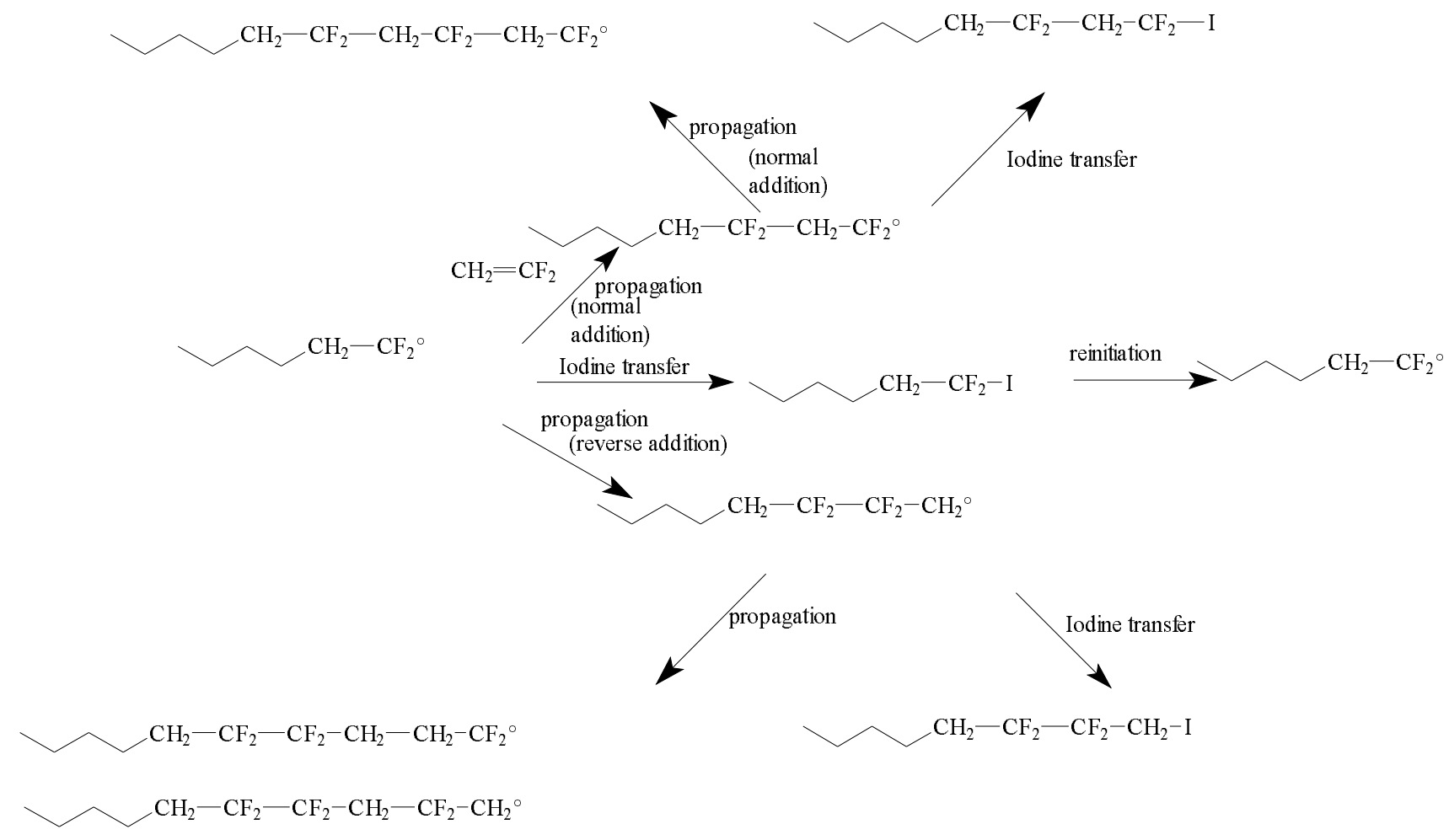

Scheme 2. Different reactions that occur in Iodine Transfer Polymerization of vinylidene fluoride. 


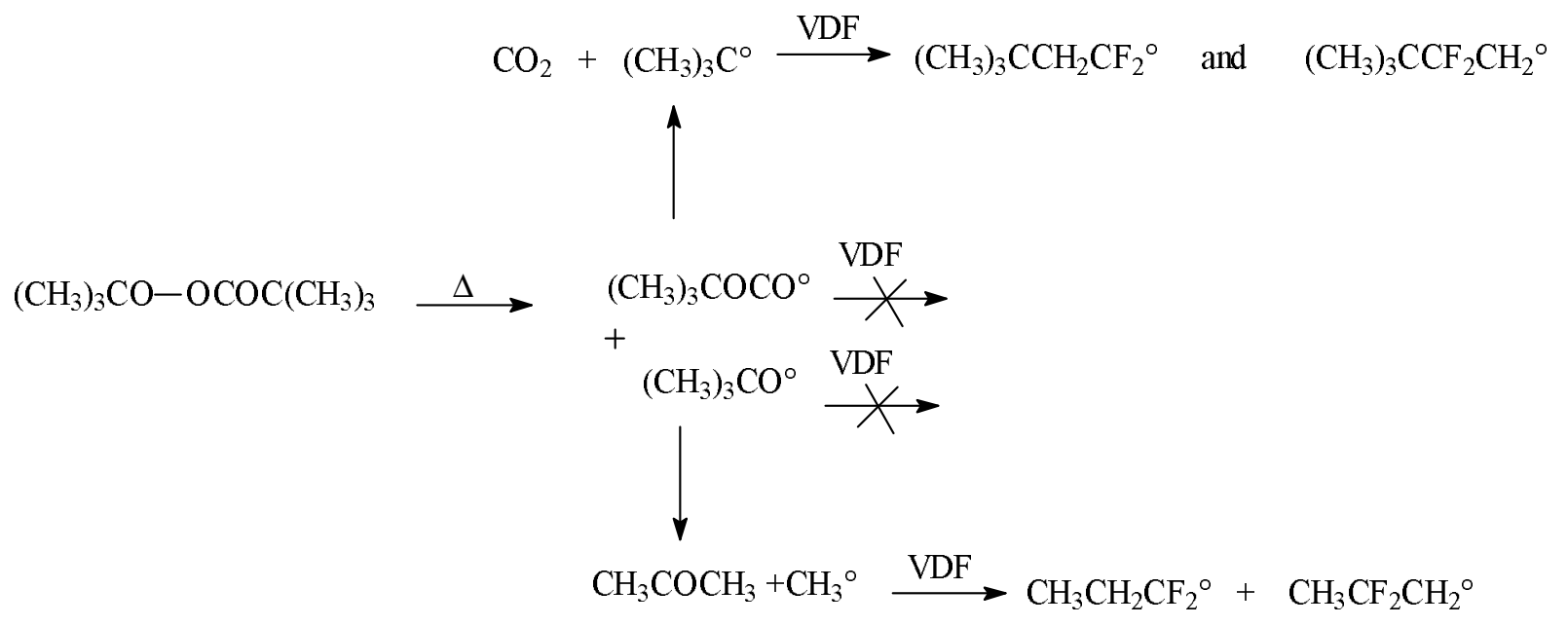

Scheme 3. Decomposition of Tert-butylperoxypivalate, formation of the radicals and their addition onto vinylidene fluoride ${ }^{23}$. 


\section{Figure Captions}

Figure 1. ${ }^{19} \mathrm{~F}$ NMR spectrum of the poly(vinylidene fluorine)-I (recorded in deuterated acetone; $200 \mathrm{MHz}, 298 \mathrm{~K}$ ) (Average number degree of polymerization $\left(\overline{\mathrm{DP}}_{\mathrm{n}}\right)=13$ ).

Experimental conditions of Iodine Transfer Polymerization of vinylidene fluorine with $\mathrm{C}_{6} \mathrm{~F}_{13} \mathrm{I}:[V D F]_{0}:\left[C_{6} F_{13} I\right]_{0}:$ [Tert-butylperoxypivalate $]_{0}=100.0: 6.6: 0.6 \mathrm{at} 75^{\circ} \mathrm{C}$.

Figure 2. ${ }^{1} \mathrm{H}$ NMR spectrum of the poly(vinylidene fluorine)-I after precipitation (recorded in deuterated acetone; $200 \mathrm{MHz}, 298 \mathrm{~K}$ ) (Average number degree of polymerization $\left(\overline{\mathrm{DP}}_{\mathrm{n}}\right)=$ 13).

Experimental conditions of Iodine Transfer Polymerization of vinylidene fluorine with $\mathrm{C}_{6} \mathrm{~F}_{13} \mathrm{I}:[V D F]_{0}:\left[C_{6} F_{13} I\right]_{0}:$ [Tert-butylperoxypivalate $]_{0}=100.0: 6.6: 0.6$ at $75^{\circ} \mathrm{C}$.

Figure 3. ${ }^{19} \mathrm{~F}$ NMR spectrum of poly(vinylidene fluorine)-I obtained by Iodine Transfer Polymerization of vinylidene fluorine with $\mathrm{HC}_{2} \mathrm{~F}_{4} \mathrm{CH}_{2} \mathrm{I}$ (after precipitation and purification) (Average number degree of polymerization $\left(\overline{\mathrm{DP}}_{\mathrm{n}}\right)=35$, calculated from Equation 8 ) (recorded in deuterated dimethylformamide; $250 \mathrm{MHz}, 298 \mathrm{~K}$ ).

Experimental conditions of Iodine Transfer Polymerization of vinylidene fluorine with $\mathrm{HC}_{2} \mathrm{~F}_{4} \mathrm{CH}_{2} \mathrm{I}:[V D F]:\left[\mathrm{HC}_{2} \mathrm{~F}_{4}-\mathrm{CH}_{2} \mathrm{I}\right]:\left[\right.$ Tert-butylperoxypivalate] $=100.0: 6.6: 0.6$ at $75^{\circ} \mathrm{C}$.

Figure 4. ${ }^{1} \mathrm{H}$ NMR spectrum of poly(vinylidene fluorine)-I obtained by Iodine Transfer Polymerization of vinylidene fluorine with $\mathrm{HC}_{2} \mathrm{~F}_{4} \mathrm{CH}_{2} \mathrm{I}$ (after precipitation and purification) (Average number degree of polymerization $\left(\overline{\mathrm{DP}}_{\mathrm{n}}\right)=35$, calculated from Equation 8 ) (recorded in deuterated dimethylformamide (DMF); $250 \mathrm{MHz}, 298 \mathrm{~K}$,).

Experimental conditions of Iodine Transfer Polymerization of vinylidene fluorine with $\mathrm{HC}_{2} \mathrm{~F}_{4} \mathrm{CH}_{2} \mathrm{I}:[\mathrm{VDF}]_{0}:\left[\mathrm{HC}_{2} \mathrm{~F}_{4} \mathrm{CH}_{2} \mathrm{I}_{0}: \text { : Tert-butylperoxypivalate }\right]_{0}=100.0: 6.6: 0.6$ at 75 ${ }^{\circ} \mathrm{C}$. 


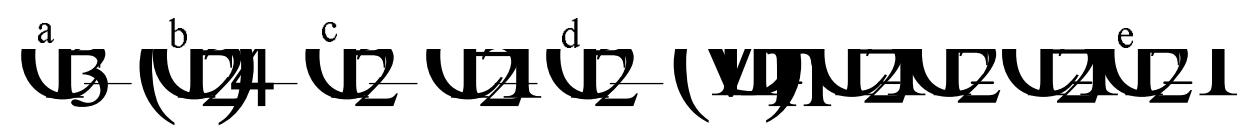 \\ (ㄱ)}

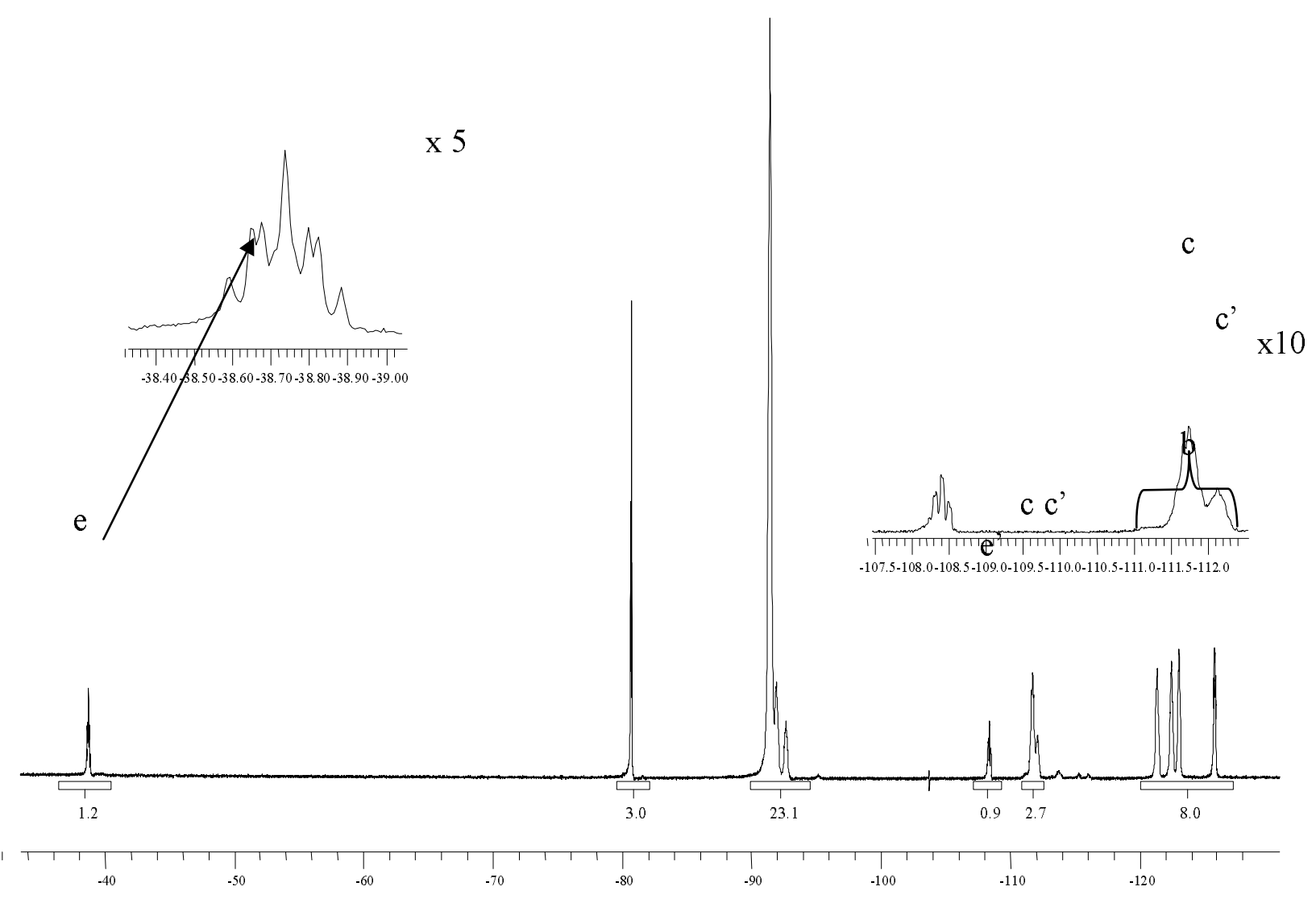

Figure 1. ${ }^{19} \mathrm{~F}$ NMR spectrum of the poly(vinylidene fluorine)-I (recorded in deuterated acetone; $200 \mathrm{MHz}, 298 \mathrm{~K}$ ) (Average number degree of polymerization $\left(\overline{\mathrm{DP}}_{\mathrm{n}}\right)=13$ ).

Experimental conditions of Iodine Transfer Polymerization of vinylidene fluorine with $\mathrm{C}_{6} \mathrm{~F}_{13} \mathrm{I}:[\mathrm{VDF}]_{0}:\left[\mathrm{C}_{6} \mathrm{~F}_{13} \mathrm{I}\right]_{0}:$ [Tert-butylperoxypivalate $]_{0}=100.0: 6.6: 0.6$ at $75^{\circ} \mathrm{C}$. 


$$
\begin{aligned}
& \mathrm{CF}_{3}-\left(\mathrm{CF}_{2}\right)_{4}-\mathrm{CF}_{2}-\mathrm{CH}_{2}-\mathrm{CF}_{2}-\left(\mathrm{CH}_{2}-\mathrm{CF}_{2}\right)_{\mathrm{n}-2}-\mathrm{CF}_{2}-\mathrm{Ch}_{2}-\mathrm{I} \\
& \mathrm{CF}_{3}-\left(\mathrm{CF}_{2}\right)_{4}-\mathrm{CF}_{2}-\stackrel{\mathrm{f}}{\mathrm{CH}_{2}}-\mathrm{CF}_{2}-\left(\mathrm{CH}_{2}-\mathrm{CF}_{2}\right)_{\mathrm{n}-2}-\stackrel{\mathrm{h}}{\mathrm{C}} \mathrm{H}_{2}-\mathrm{CF}_{2}-\mathrm{I}
\end{aligned}
$$

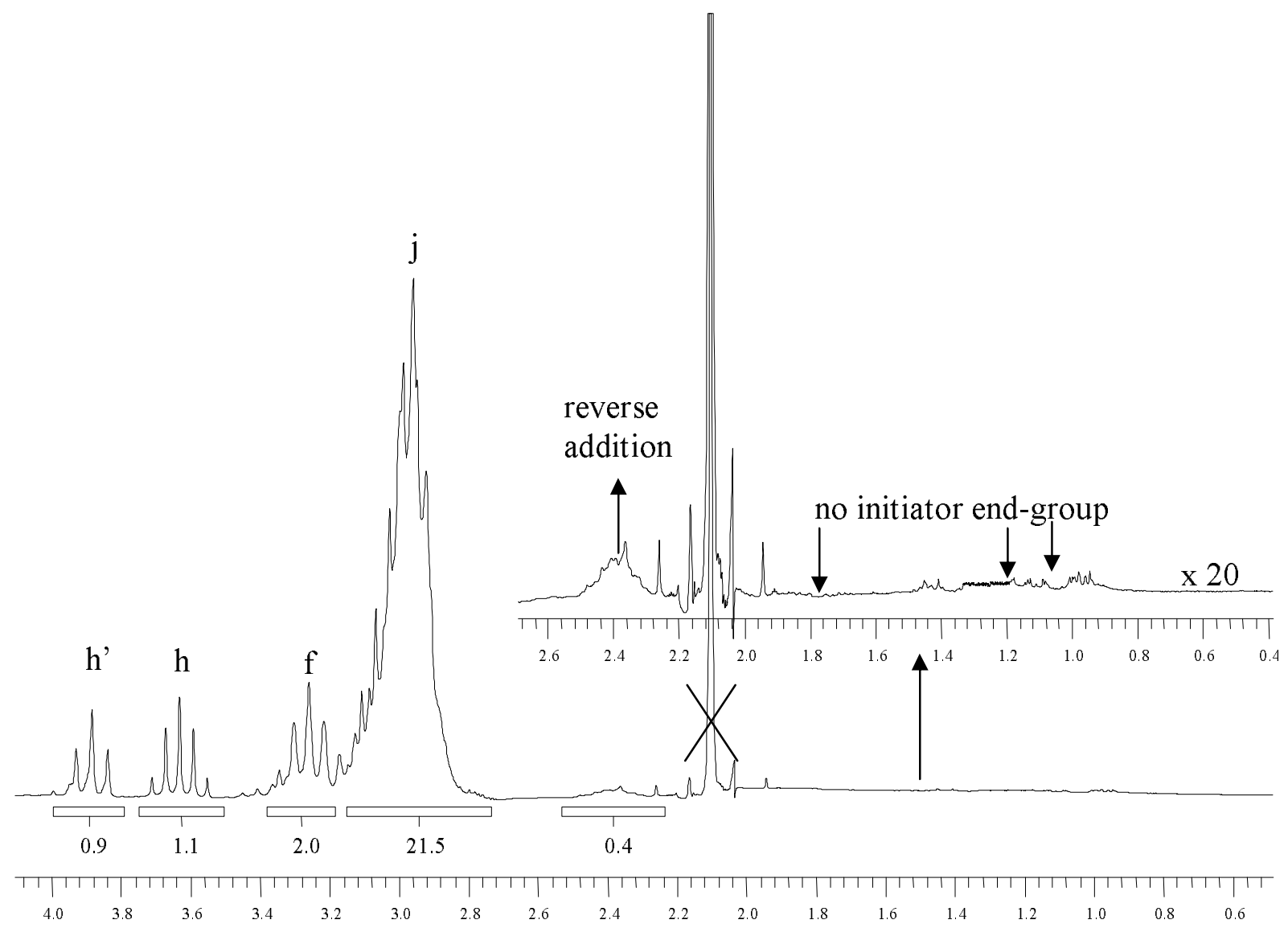

Figure 2. ${ }^{1} \mathrm{H}$ NMR spectrum of the poly(vinylidene fluorine)-I after precipitation (recorded in deuterated acetone; $200 \mathrm{MHz}, 298 \mathrm{~K}$ ) (Average number degree of polymerization $\left(\overline{\mathrm{DP}}_{\mathrm{n}}\right)=$ 13).

Experimental conditions of Iodine Transfer Polymerization of vinylidene fluorine with $\mathrm{C}_{6} \mathrm{~F}_{13} \mathrm{I}:[V D F]_{0}:\left[C_{6} F_{13} I\right]_{0}:$ [Tert-butylperoxypivalate $]_{0}=100.0: 6.6: 0.6$ at $75^{\circ} \mathrm{C}$. 


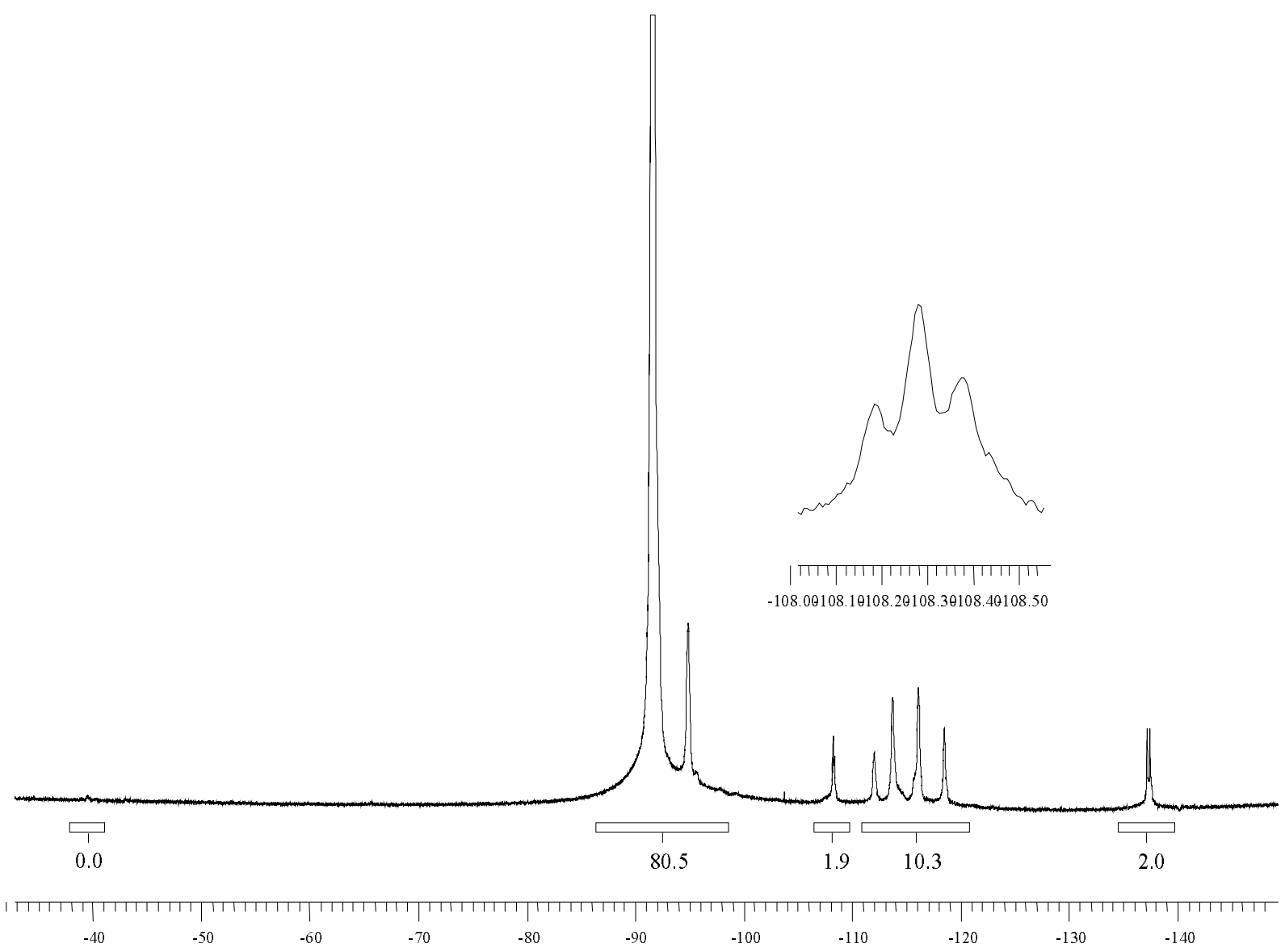

Figure 3. ${ }^{19} \mathrm{~F}$ NMR spectrum of poly(vinylidene fluorine)-I obtained by Iodine Transfer Polymerization of vinylidene fluorine with $\mathrm{HC}_{2} \mathrm{~F}_{4} \mathrm{CH}_{2} \mathrm{I}$ (after precipitation and purification) (Average number degree of polymerization $\left(\overline{\mathrm{DP}}_{\mathrm{n}}\right)=35$, calculated from Equation 8) (recorded in deuterated dimethylformamide; $250 \mathrm{MHz}, 298 \mathrm{~K}$ ).

Experimental conditions of Iodine Transfer Polymerization of vinylidene fluorine with $\mathrm{HC}_{2} \mathrm{~F}_{4} \mathrm{CH}_{2} \mathrm{I}:[V D F]:\left[\mathrm{HC}_{2} \mathrm{~F}_{4}-\mathrm{CH}_{2} \mathrm{I}\right]:\left[\right.$ Tert-butylperoxypivalate] $=100.0: 6.6: 0.6$ at $75^{\circ} \mathrm{C}$. 


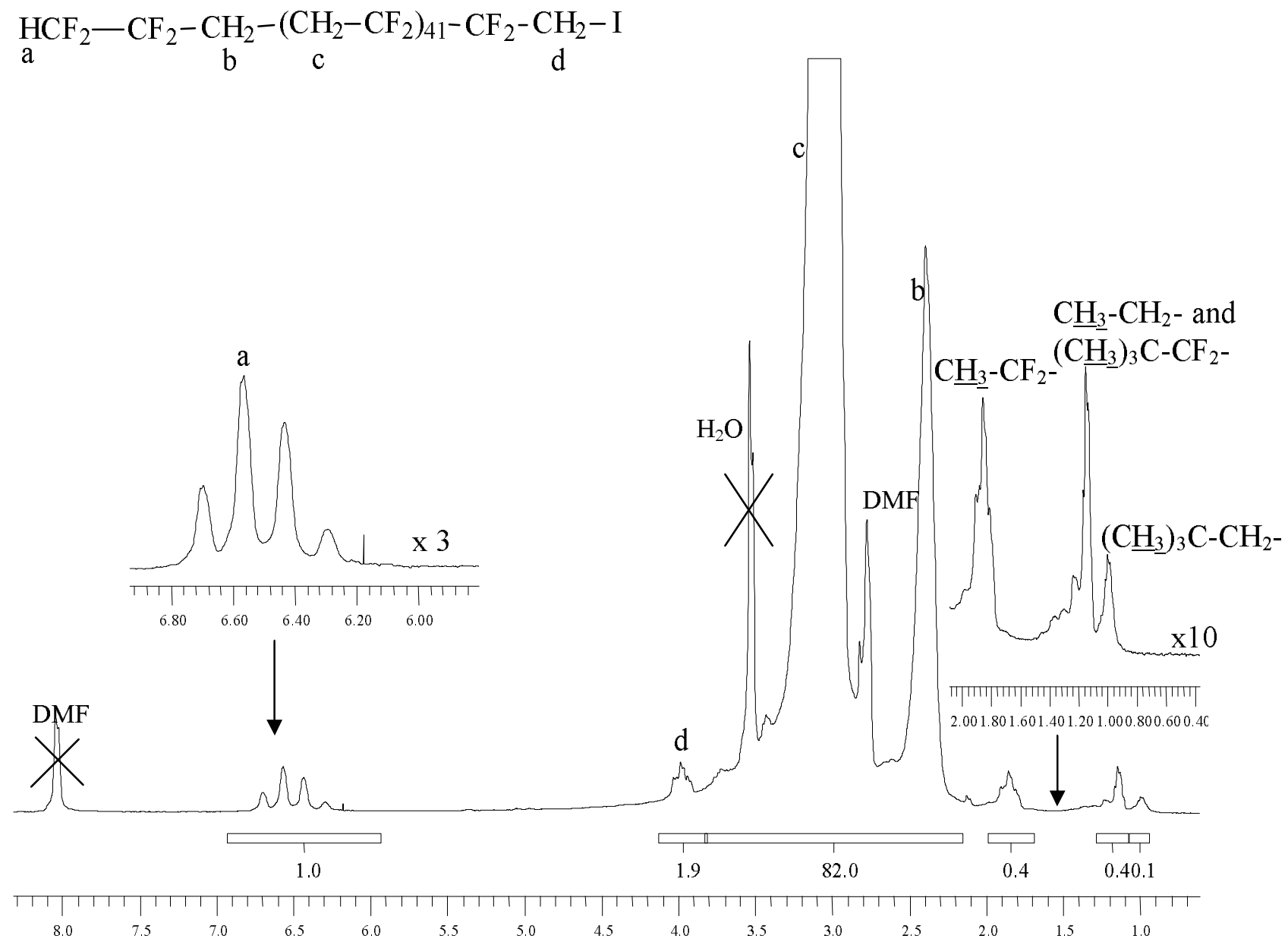

Figure 4. ${ }^{1} \mathrm{H}$ NMR spectrum of poly(vinylidene fluorine)-I obtained by Iodine Transfer Polymerization of vinylidene fluorine with $\mathrm{HC}_{2} \mathrm{~F}_{4} \mathrm{CH}_{2} \mathrm{I}$ (after precipitation and purification) (Average number degree of polymerization $\left(\overline{\mathrm{DP}}_{\mathrm{n}}\right)=35$, calculated from Equation 8 ) (recorded in deuterated dimethylformamide (DMF); $250 \mathrm{MHz}, 298 \mathrm{~K}$ ).

Experimental conditions of Iodine Transfer Polymerization of vinylidene fluorine with $\mathrm{HC}_{2} \mathrm{~F}_{4} \mathrm{CH}_{2} \mathrm{I}:[\mathrm{VDF}]_{0}:\left[\mathrm{HC}_{2} \mathrm{~F}_{4} \mathrm{CH}_{2} \mathrm{I}_{0}: \text { : Tert-butylperoxypivalate }\right]_{0}=100.0: 6.6: 0.6$ at 75 ${ }^{\circ} \mathrm{C}$. 


\section{Table Captions}

Table 1. Iodine transfer polymerisation of fluoroalkenes for the synthesis of fluorinated Hardb-Soft-b-Hard triblock copolymers (n.g. stands for not given).

a) VDF, HFP, TFE, CTFE, PMVE, FVA, $\mathrm{E}$ and $\mathrm{P}$ represent vinylidene fluoride, hexafluoropropene, tetrafluoroethylene, chlorotrifluoroethylene, perfluoromethylvinylether, perfluoro vinylacetic acid, ethylene, and propylene, respectively.

b) also tetrapolymerisation with less than $1 \mathrm{~mol} \%$ of $\mathrm{H}_{2} \mathrm{C}=\mathrm{CH}-\mathrm{C}_{6} \mathrm{~F}_{12}-\mathrm{CH}=\mathrm{CH}_{2}$.

c) also tetrapolymerisation with less than 1 mol.\% of $\mathrm{H}_{2} \mathrm{C}=\mathrm{CH}-\mathrm{C}_{6} \mathrm{~F}_{12}-\mathrm{CH}=\mathrm{CH}_{2}$ / $\mathrm{H}_{2} \mathrm{C}=\mathrm{CHC}_{6} \mathrm{~F}_{12} \mathrm{C}_{2} \mathrm{H}_{4} \mathrm{I} / \mathrm{IC}_{2} \mathrm{H}_{4} \mathrm{C}_{6} \mathrm{~F}_{12} \mathrm{C}_{2} \mathrm{H}_{4} \mathrm{I}$ mixture.

Table 2. Assignments of ${ }^{19} \mathrm{~F}$ NMR chemical shifts in poly(vinylidene fluorine)-I. (s: singlet, $\mathrm{d}$ : doublet, t: triplet, m: multiplet).

Table 3. Assignments of ${ }^{1} \mathrm{H}$ NMR chemical shifts in poly(vinylidene fluorine)-I. (s: singlet; $t$ : triplet; q: quintet; m: multiplet).

Table 4. Summary of average number degree of polymerization $\left(\overline{\mathrm{DP}}_{\mathrm{n}}\right)$ for various concentrations in chain transfer agent $\left(\mathrm{CTA}: \mathrm{C}_{6} \mathrm{~F}_{13}-\mathrm{I}\right)$

a- temperature : $75{ }^{\circ} \mathrm{C}$; b- calculated by Equation 1; c- determined by ${ }^{19} \mathrm{~F}$ and ${ }^{1} \mathrm{H}$ NMR (Equations 2 and 3); d- conversion of monomer assessed by gravimetry:

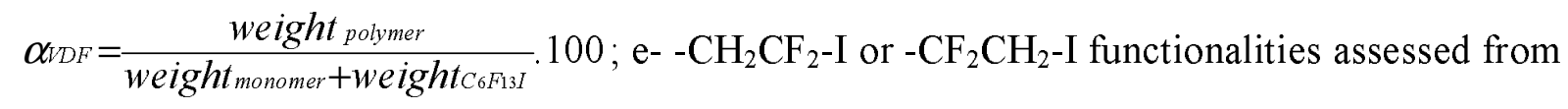
${ }^{19} \mathrm{~F}$ and ${ }^{1} \mathrm{H}$ NMR ; f- $-\mathrm{CH}_{2} \mathrm{CF}_{2}$-I functionality determined from Equation 6.

Table 5. Variation of the functionality in $-\mathrm{CF}_{2}-\mathrm{I}$ for various fractions of oligomers (fractionation of poly(vinylidene fluorine)-I; (average number degree of polymerization, $\overline{\mathrm{DP}}_{\mathrm{n}}=25$ ). a- assessed by ${ }^{1} \mathrm{H} \mathrm{NMR}$; b- $-\mathrm{CH}_{2} \mathrm{CF}_{2}$-I functionality determined from ${ }^{19} \mathrm{~F}$ NMR (Equation 4).

Table 6. Summary of average number degree of polymerization ( $\left.\overline{\mathrm{DP}}_{\mathrm{n}}\right)$ for Iodine Transfer Polymerization reaction performed with various concentrations of $\mathrm{HC}_{2} \mathrm{~F}_{4} \mathrm{CH}_{2} \mathrm{I}$, and with two initiators $\left[\mathrm{A}_{2}\right]:$ [Tert-butylperoxypivalate $]$ at $75^{\circ} \mathrm{C}$ and $[2,5$-bis(tert-butylperoxide)-2,5dimethylhexane] at $135^{\circ} \mathrm{C}$.

a- calculated from Equation 2; b- determined by ${ }^{19} \mathrm{~F}$ NMR (eq. 7); determined by ${ }^{1} \mathrm{H}$ NMR (eq. 8); d- monomer conversion measured by gravimetry ( $\mathrm{R}$ massic yield) : $R=\frac{\text { weight polymer }}{\text { weight monomer }+ \text { weight } \mathrm{HCF}_{2} \mathrm{CF}_{2} \mathrm{CH}_{2} \mathrm{I}} .100$; e- conversion of $\mathrm{HC}_{2} \mathrm{~F}_{4} \mathrm{CH}_{2} \mathrm{I}$; f- functionality in $\mathrm{CF}_{2} \mathrm{I}$ 
(determined by ${ }^{19} \mathrm{~F}$ NMR (from eq.4); g- chain percentage resulting from direct initiation (Eq. 9). 


\begin{tabular}{|c|c|c|c|c|c|c|}
\hline Soft block ${ }^{\text {a) }}$ & $\begin{array}{c}\% \\
\text { comonomers } \\
\text { in soft block }\end{array}$ & Hard block & $\begin{array}{c}\text { Soft / Hard } \\
\text { Ratio (wt\%) }\end{array}$ & $\begin{array}{l}\mathrm{Tg} \\
\left({ }^{\circ} \mathrm{C}\right)\end{array}$ & $\begin{array}{l}\mathbf{T}_{\mathbf{m}} \\
\left({ }^{\circ} \mathrm{C}\right)\end{array}$ & Ref. \\
\hline $\mathrm{I}\left[(\mathrm{VDF})_{\mathrm{x}} \mathrm{HFP}\right]_{\mathrm{y}} \mathrm{I}$ & n.g. & PVDF & n.g. & n.g. & 160 & 14 \\
\hline $\mathrm{I}\left[(\mathrm{VDF})_{\mathrm{X}} \mathrm{HFP}\right]_{\mathrm{y}} \mathrm{I}$ & n.g. & poly(E-alt-TFE) & n.g. & n.g. & 220 & 14 \\
\hline $\mathrm{I}\left[(\mathrm{CTFE})_{\mathrm{x}}(\mathrm{VDF})_{\mathrm{y}}\right]_{\mathrm{z}} \mathrm{I}$ & $45 / 55$ & poly(E-co-CTFE) & $85 / 15$ & -6 & 247 & 7 \\
\hline $\mathrm{I}\left[(\mathrm{CTFE})_{\mathrm{x}}(\mathrm{VDF})_{\mathrm{y}}\right]_{\mathrm{z}} \mathrm{I}$ & $45 / 55$ & poly(E-co-TFE) & $90 / 10$ & -8 & 252 & 7 \\
\hline $\mathrm{I}\left[(\mathrm{VDF})_{\mathrm{x}}(\mathrm{FVA})_{\mathrm{y}}\right]_{\mathrm{z}} \mathrm{I}$ & n.g. & PVDF & n.g. & n.g. & n.g. & 14 \\
\hline $\mathrm{I}\left[(\mathrm{TFE})_{\mathrm{X}} \mathrm{P}\right]_{\mathrm{y}} \mathrm{I}$ & $55 / 45$ & poly(E-co-TFE) & $80 / 20$ & -1 & 267 & 9 \\
\hline $\mathrm{I}\left[(\mathrm{VDF})_{\mathrm{x}} \mathrm{HFP}(\mathrm{TFE})_{\mathrm{y}}\right]_{\mathrm{z}} \mathrm{I}^{\mathrm{b}) \mathrm{c})}$ & $56 / 19 / 25$ & PVDF & $80 / 20$ & $\begin{array}{c}-12 \text { to } \\
-15\end{array}$ & 165 & 11,12 \\
\hline $\mathrm{I}\left[(\mathrm{VDF})_{\mathrm{X}} \mathrm{HFP}(\mathrm{TFE})_{\mathrm{y}}\right]_{\mathrm{z}} \mathrm{I}$ & $35 / 40 / 25(w t)$ & poly(E-alt-TFE) & n.g. & -8 & 222 & 14 \\
\hline $\mathrm{I}\left[(\mathrm{VDF})_{\mathrm{X}} \mathrm{HFP}(\mathrm{TFE})_{\mathrm{y}}\right]_{\mathrm{z}} \mathrm{I}$ & $50 / 30 / 20$ & poly(E-co-HFP-co-TFE) & $85 / 15$ & n.g. & n.g. & 7 \\
\hline $\left.\mathrm{I}\left[(\mathrm{VDF})_{\mathrm{X}} \mathrm{HFP}(\mathrm{TFE})_{\mathrm{y}}\right]_{\mathrm{z}} \mathrm{I}^{\mathrm{b}}\right)$ & $54 / 21 / 25$ & poly(E-alt-TFE) & $80 / 20$ & -13 & 266 & 11 \\
\hline $\mathrm{I}\left[(\mathrm{VDF})_{\mathrm{X}} \mathrm{PMVE}(\mathrm{TFE})_{\mathrm{y}}\right]_{\mathrm{z}} \mathrm{I}^{\mathrm{b})}$ & $62 / 19 / 19$ & PVDF & $80 / 20$ & -30 & 160 & 11,13 \\
\hline $\mathrm{I}\left[(\mathrm{VDF})_{\mathrm{x}} \mathrm{PMVE}(\mathrm{TFE})_{\mathrm{y}}\right]_{\mathrm{z}} \mathrm{I}$ & $73 / 17 / 10$ & poly(E-co-TFE) & $72 / 28$ & -33 & 254 & 9 \\
\hline $\mathrm{I}\left[(\mathrm{VDF})_{\mathrm{x}} \mathrm{PMVE}(\mathrm{TFE})_{\mathrm{y}}\right]_{\mathrm{z}} \mathrm{I}^{\mathrm{b})}$ & n.g. & poly(E-co-TFE) & n.g. & $\begin{array}{c}-13 \text { to } \\
-15\end{array}$ & 266 & 11,12 \\
\hline $\mathrm{I}\left[(\mathrm{VDF})_{\mathrm{x}} \mathrm{PMVE}(\mathrm{TFE})_{\mathrm{y}}\right]_{\mathrm{z}} \mathrm{I}^{\mathrm{b})}$ & $57 / 23 / 20$ & poly(E-co-TFE-co-PMVE) & $75 / 25$ & n.g. & 180 & 13 \\
\hline $\mathrm{I}\left[(\mathrm{TFE})_{\mathrm{X}} \mathrm{P}(\mathrm{VDF})_{\mathrm{y}}\right]_{\mathrm{z}} \mathrm{I}$ & n.g. & poly(E-co-TFE) & $85 / 15$ & -13 & 262 & 9 \\
\hline $\mathrm{I}\left[(\mathrm{TFE})_{\mathrm{X}} \mathrm{E}(\mathrm{PMVE})_{\mathrm{y}}\right]_{\mathrm{z}} \mathrm{I}$ & $45 / 19 / 36$ & poly(E-co-TFE) & $71 / 29$ & -16 & 245 & 9 \\
\hline
\end{tabular}

Table 1. Iodine transfer polymerisation of fluoroalkenes for the synthesis of fluorinated Hardb-Soft-b-Hard triblock copolymers (n.g. stands for not given).

a) VDF, HFP, TFE, CTFE, PMVE, FVA, E and $\mathrm{P}$ represent vinylidene fluoride, hexafluoropropene, tetrafluoroethylene, chlorotrifluoroethylene, perfluoromethylvinylether, perfluoro vinylacetic acid, ethylene, and propylene, respectively.

b) also tetrapolymerisation with less than 1 mol. $\%$ of $\mathrm{H}_{2} \mathrm{C}=\mathrm{CH}-\mathrm{C}_{6} \mathrm{~F}_{12}-\mathrm{CH}=\mathrm{CH}_{2}$.

c) also tetrapolymerisation with less than 1 mol.\% of $\mathrm{H}_{2} \mathrm{C}=\mathrm{CH}-\mathrm{C}_{6} \mathrm{~F}_{12}-\mathrm{CH}=\mathrm{CH}_{2}$ / $\mathrm{H}_{2} \mathrm{C}=\mathrm{CHC}_{6} \mathrm{~F}_{12} \mathrm{C}_{2} \mathrm{H}_{4} \mathrm{I} \quad / \quad \mathrm{IC}_{2} \mathrm{H}_{4} \mathrm{C}_{6} \mathrm{~F}_{12} \mathrm{C}_{2} \mathrm{H}_{4} \mathrm{I}$ mixture. 


\begin{tabular}{|c|c|c|}
\hline$\delta(\mathrm{ppm})$ & Signal & Assignment \\
\hline-38.0 & $\mathrm{t}\left({ }^{3} \mathrm{~J}_{\mathrm{FH}}=7.0 \mathrm{~Hz}\right) \mathrm{t}\left({ }^{4} \mathrm{~J}_{\mathrm{FF}}=9.8 \mathrm{~Hz}\right)$ & $-\mathrm{CH}_{2}-\mathrm{CF}_{2} \mathrm{I}$ \\
\hline-60.0 & $\mathrm{~m}$ & $-\mathrm{CF}_{2}-\mathrm{CF}_{2} \mathrm{I}$ \\
\hline-82.0 & $\mathrm{~m}$ & $\mathrm{CF}_{\underline{3}}-\mathrm{CF}_{2^{-}}$ \\
\hline-91.0 & $\mathrm{~m}$ & $-\mathrm{CH}_{2}-\mathrm{CF}_{2}-\mathrm{CH}_{2}-\mathrm{CF}_{2^{-}}$ \\
\hline-95.7 & $\mathrm{~m}$ & $\mathrm{CH}_{3}-\mathrm{CH}_{2}-\mathrm{CF}_{2}-$ \\
\hline-108.0 & $\mathrm{~m}$ & $\begin{array}{c}\mathrm{CH}_{3}-\mathrm{CF}_{2}- \\
-\mathrm{CF}_{2}-\mathrm{CF}_{2}-\mathrm{CH}_{2}-\mathrm{I} \\
-\mathrm{CF}_{2}-\mathrm{CF}_{2}-{ }^{-} \mathrm{CH}_{2}-\mathrm{CF}_{2}-\end{array}$ \\
\hline-112.0 & $\mathrm{~m}$ & $\left(\mathrm{CH}_{3}\right)_{3} \mathrm{C}-\mathrm{CF}_{2}-\mathrm{CH}_{2^{-}}$ \\
\hline-113.4 & $\mathrm{~m}$ & $-\mathrm{CH}_{2}-\mathrm{CF}_{2}-\mathrm{CF}_{2}-\mathrm{CH}_{2}-\mathrm{CH}_{2}-$ \\
\hline-115.7 & $\mathrm{~m}$ & $-\mathrm{CH}_{2}-\mathrm{CF}_{2}-\mathrm{CF}_{2}-\mathrm{CH}_{2}-\mathrm{CH}_{2}-$ \\
\hline-138.0 & $\mathrm{dm}$ & $\mathrm{HCF}_{2}-\mathrm{CF}_{2^{-}}$ \\
\hline
\end{tabular}

Table 2. Assignments of ${ }^{19} \mathrm{~F}$ NMR chemical shifts in poly(vinylidene fluorine)-I. (s: singlet, $\mathrm{d}$ : doublet, t: triplet, $\mathrm{m}$ : multiplet). 


\begin{tabular}{|c|c|c|}
\hline$\delta(\mathrm{ppm})$ & Signal & Assignment \\
\hline 1.0 & $\mathrm{~s}$ & $\left(\mathrm{C}_{\mathrm{H}_{3}}\right)_{3} \mathrm{CCH}_{2}-\mathrm{CF}_{2^{-}}$ \\
\hline 1.2 & $\mathrm{t}$ & $\mathrm{CH}_{3}-\mathrm{CH}_{2}-\mathrm{CF}_{2}-$ \\
\hline 1.3 & $\mathrm{~s}$ & $\left(\mathrm{CH}_{3}\right)_{3} \mathrm{CCF}_{2}-\mathrm{CH}_{2}-$ \\
\hline 1.8 & $\mathrm{t}$ & $\mathrm{C}_{\underline{3}}-\mathrm{CF}_{2}-\mathrm{CH}_{2}-$ \\
\hline 2.3 & $\mathrm{~m}$ & $-\mathrm{CH}_{2}-\mathrm{CF}_{2}-\mathrm{CF}_{2}-\mathrm{CH}_{2}-\underline{\mathrm{CH}}_{2}-\mathrm{CF}_{2}-$ \\
\hline 2.9 & $\mathrm{~m}$ & $\begin{array}{c}-\mathrm{CH}_{2}-\mathrm{CF}_{2}-\mathrm{CH}_{2}-\mathrm{CF}_{2}-\mathrm{CH}_{2}-\mathrm{CF}_{2}- \\
\mathrm{CH}_{3}-\mathrm{C}_{2}-\mathrm{CF}_{2^{-}} \\
\left(\mathrm{CH}_{3}\right)_{3} \underline{\mathrm{C}}_{\underline{H}_{2}}-\mathrm{CF}_{2^{-}}\end{array}$ \\
\hline 3.3 & $q$ & $\mathrm{C}_{6} \mathrm{~F}_{13}-\mathrm{CH}_{2}-\mathrm{CF}_{2-}$ \\
\hline 3.7 & $q$ & $-\mathrm{CH}_{2}-\mathrm{CF}_{2}-\mathrm{I}$ \\
\hline 3.9 & $q$ & $-\mathrm{CF}_{2}-\underline{C}_{2}-\mathrm{I}$ \\
\hline 6.5 & $\mathrm{t}\left({ }^{2} \mathrm{~J}_{\mathrm{HF}}=49.6 \mathrm{~Hz}\right) \mathrm{t}\left({ }^{3} \mathrm{~J}_{\mathrm{HF}}=4.0 \mathrm{~Hz}\right)$ & $\underline{\mathrm{HCF}_{2}} \mathrm{CF}_{2}$ \\
\hline
\end{tabular}

Table 3. Assignments of ${ }^{1} \mathrm{H}$ NMR chemical shifts in poly(vinylidene fluorine)-I. (s: singlet; $t$ : triplet; q: quintet; m: multiplet). 


\begin{tabular}{|c|c|c|c|c|c|c|c|c|c|}
\hline \multirow{3}{*}{ Run } & \multirow{3}{*}{$\begin{array}{c}\text { Concentration ratios } \\
{[\mathrm{VDF}]_{0}: \text { [Chain transfer }} \\
\text { agent }]_{0}: \text { [Tert- } \\
\text { butylperoxypivalate }]_{0}\end{array}$} & \multirow{3}{*}{$\begin{array}{c}\text { Targeted }^{\mathrm{b}} \\
\overline{\mathrm{DP}}_{\mathrm{n}} \\
(\alpha=100)\end{array}$} & \multirow{3}{*}{$\begin{array}{c}\text { Experimental }^{\mathrm{c}} \\
\overline{\mathrm{DP}}_{\mathrm{n}}\end{array}$} & \multirow{3}{*}{$\begin{array}{c}\alpha_{\mathrm{VDF}}{ }^{\mathrm{d}} \\
(\%)\end{array}$} & \multicolumn{4}{|c|}{ functionality $_{\exp .}{ }^{e}$} & functionality theo. \\
\hline & & & & & \multicolumn{2}{|c|}{$\begin{array}{c}-\mathrm{CF}_{2}-\mathrm{I} \\
(\%)\end{array}$} & \multicolumn{2}{|c|}{$\begin{array}{c}-\mathrm{CH}_{2}-\mathrm{I} \\
(\%)\end{array}$} & \multirow[t]{2}{*}{$\begin{array}{l}-\mathrm{CF}_{2}-\mathrm{I} \\
(\%)^{\mathrm{f}}\end{array}$} \\
\hline & & & & & ${ }^{19} \mathrm{~F}$ & ${ }^{1} \mathrm{H}$ & ${ }^{19} \mathrm{~F}$ & ${ }^{1} \mathrm{H}$ & \\
\hline M1 & 100.0: 11.0: 1.1 & 9 & 6 & 70 & 75 & 78 & 25 & 22 & 77 \\
\hline M2 & $100.0: 10.0: 1.0$ & 10 & 9 & 90 & 68 & 65 & 32 & 35 & 66 \\
\hline M3 & 100.0: $6.6: 0.6$ & 15 & 13 & 70 & 60 & 55 & 46 & 35 & 54 \\
\hline M4 & $100.0: 3.3: 0.3$ & 30 & 25 & 75 & 28 & 29 & 72 & 71 & 29 \\
\hline
\end{tabular}

Table 4. Summary of average number degree of polymerization ( $\left.\overline{\mathrm{DP}}_{\mathrm{n}}\right)$ for various concentrations in chain transfer agent (CTA: $\left.\mathrm{C}_{6} \mathrm{~F}_{13}-\mathrm{I}\right)$

a- temperature : $75{ }^{\circ} \mathrm{C}$; b- calculated by Equation 1; c- determined by ${ }^{19} \mathrm{~F}$ and ${ }^{1} \mathrm{H}$ NMR (Equations 2 and 3); d- conversion of monomer assessed by gravimetry:

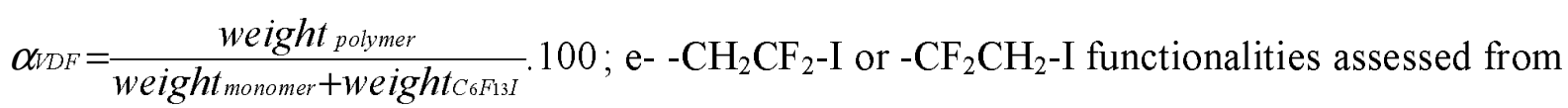
${ }^{19} \mathrm{~F}$ and ${ }^{1} \mathrm{H}$ NMR ; f- $-\mathrm{CH}_{2} \mathrm{CF}_{2}$-I functionality determined from Equation 6. 


\begin{tabular}{|c|c|c|c|c|c|}
\hline \multirow{3}{*}{ Fractions } & \multirow{3}{*}{ Initial $\overline{\mathrm{DP}}_{n}$} & \multirow{3}{*}{$\begin{array}{l}\text { Experimental }^{\mathrm{a}} \\
\qquad \overline{\mathrm{DP}}_{\mathrm{n}} \\
\text { of each fraction }\end{array}$} & \multirow{3}{*}{$\begin{array}{l}\text { Weight of } \\
\text { the fraction } \\
\text { (g) }\end{array}$} & \multicolumn{2}{|c|}{ functionality $_{\exp }\left(f_{\text {exp. }}\right)$} \\
\hline & & & & \multicolumn{2}{|c|}{$\begin{array}{c}-\mathrm{CF}_{2}-\mathrm{I} \\
(\%)^{\mathrm{b}}\end{array}$} \\
\hline & & & & ${ }^{1} \mathrm{H}$ & ${ }^{19} \mathrm{~F}$ \\
\hline $\mathrm{F} 1$ & 25 & 5 & 10 & 0 & 0 \\
\hline $\mathrm{F} 2$ & 25 & 15 & 50 & 5 & 5 \\
\hline F3 & 25 & 35 & 40 & 50 & 45 \\
\hline
\end{tabular}

Table 5. Variation of the functionality in $-\mathrm{CF}_{2}-\mathrm{I}$ for various fractions of oligomers (fractionation of poly(vinylidene fluorine)-I; (average degree of polymerization, $\overline{\mathrm{DP}}_{\mathrm{n}}=25$ ). a- assessed by ${ }^{1} \mathrm{H}$ NMR; b- - $\mathrm{CH}_{2} \mathrm{CF}_{2}$-I functionality determined by ${ }^{19} \mathrm{~F}$ NMR (Equation 4). 


\begin{tabular}{|c|c|c|c|c|c|c|c|c|}
\hline Reactions & $\begin{array}{c}\text { Concentration } \\
\text { ratios } \\
{[\mathrm{VDF}]_{0}:} \\
{\left[\mathrm{HC}_{2} \mathrm{~F}_{4} \mathrm{CH}_{2}[]_{0}:\right.} \\
{\left[\mathrm{A}_{2}\right]_{0}}\end{array}$ & $\begin{array}{c}\mathrm{T} \\
\left({ }^{\circ} \mathrm{C}\right)\end{array}$ & $\begin{array}{c}\text { Targeted }^{\mathrm{a}} \\
\overline{\mathrm{DP}}_{\mathrm{n}}\end{array}$ & $\begin{array}{l}\text { Experimental } \\
\qquad \overline{\mathrm{DP}}_{\mathrm{n}}\end{array}$ & $\begin{array}{c}\alpha_{\mathrm{VDF}}{ }^{\mathrm{d}} \\
(\%)\end{array}$ & $\begin{array}{c}\alpha_{\mathrm{CTA}}{ }^{\mathrm{e}} \\
(\%)\end{array}$ & $\begin{array}{c}\mathrm{f}_{\text {exp }} . \\
\left(\mathrm{CF}_{2}-\mathrm{I}\right) \\
(\%)^{\mathrm{f}}\end{array}$ & $\begin{array}{l}(\varepsilon)^{g} \\
(\%)\end{array}$ \\
\hline M5 & 100.0: $6.6: 0.6$ & 75 & 15 & $46^{b} \quad\left(35^{c}\right)$ & 80 & 33 & 0 & 17 \\
\hline M6 & 100.0: $6.6: 0.6$ & 135 & 15 & $32^{\mathrm{b}} \quad\left(28^{\mathrm{c}}\right)$ & 80 & 66 & 0 & 13 \\
\hline M7 & $100.0: 2.5: 0.2$ & 75 & 35 & $70^{\mathrm{b}}(60)^{\mathrm{c}}$ & 80 & 33 & 0 & 14 \\
\hline M8 & $100.0: 2.5: 0.2$ & 135 & 35 & $42^{b} \quad\left(38^{c}\right)$ & 90 & 66 & 0 & 10 \\
\hline
\end{tabular}

Table 6. Summary of average degree of polymerization ( $\left.\overline{\mathrm{DP}}_{\mathrm{n}}\right)$ for Iodine Transfer Polymerization reaction performed with various concentrations of $\mathrm{HC}_{2} \mathrm{~F}_{4} \mathrm{CH}_{2} \mathrm{I}$, and with two initiators $\left[\mathrm{A}_{2}\right]:\left[\right.$ Tert-butylperoxypivalate] at $75^{\circ} \mathrm{C}$ and $[2,5$-bis(tert-butylperoxide)-2,5dimethylhexane] at $135^{\circ} \mathrm{C}$.

a- calculated from Equation 2; b- determined by ${ }^{19} \mathrm{~F}$ NMR (eq. 7); determined by ${ }^{1} \mathrm{H}$ NMR (eq. 8); d- monomer conversion measured by gravimetry ( $\mathrm{R}$ massic yield) : $R=\frac{\text { weight polymer }}{\text { weight monomer }+ \text { weight } \mathrm{HCF}_{2} \mathrm{CF}_{2} \mathrm{CH}_{2} \mathrm{I}} .100$; e- conversion of $\mathrm{HC}_{2} \mathrm{~F}_{4} \mathrm{CH}_{2} \mathrm{I}$; f- functionality in $\mathrm{CF}_{2} \mathrm{I}$ (determined by ${ }^{19} \mathrm{~F}$ NMR (from eq.4); g- chain percentage resulting from direct inintiation (Eq. 9). 


\section{SUPPORTING INFORMATION}

Experimental part

\section{Reactions in autoclave}

ITP reaction with perfluorohexyl iodide of VDF at $75^{\circ} \mathrm{C}$.

A 160-mL Hastelloy (HC-276) autoclave, equipped with inlet and outlet valves, a manometer and a rupture disc, was degassed and pressurized with 30 bar of nitrogen to check eventual leaks. Then, a $20 \mathrm{~mm} \mathrm{Hg}$ vacuum was operated for $30 \mathrm{~min}$. Under vacuum, were transfered into the autoclave $0.43 \mathrm{~g}\left(2 \times 10^{-3} \mathrm{~mol}\right)$ of tert-butylperoxypivalate, $8.92 \mathrm{~g}\left(2 \times 10^{-2}\right.$ mol) of perfluorohexyl iodide and $100 \mathrm{~g}$ of 1,1,1,3,3-pentafluorobutane. Then, by double weighing, $12.8 \mathrm{~g}\left(2 \times 10^{-1} \mathrm{~mol}\right)$ of VDF were introduced in the mixture. Afterward, the autoclave was progressively heated to $75^{\circ} \mathrm{C}$. It was observed an exotherm of ca. $10{ }^{\circ} \mathrm{C}$ and an increase of pressure from 22 bar up to 28 bar and then a sharp drop of pressure until to 18 bar. After reaction, the autoclave was placed in an ice bath for about 60 minutes and $1.20 \mathrm{~g}$ of unreacted VDF were progressively released (the conversion of VDF was $90 \%$ and the CTA conversion was $100 \%$ ) After opening the autoclave, about $120 \mathrm{~g}$ of a brown liquid were obtained. After evaporation of 1,1,1,3,3-pentafluorobutane, the sample was dissolved in DMF,

which enables solubilization of low $\overline{\mathrm{DP}}_{\mathrm{n}}$ (also soluble in acetone) and high $\overline{\mathrm{DP}}_{\mathrm{n}}$, and precipited by adding water into the DMF solution. White powder was obtained in all cases and ${ }^{19}$ F NMR led to a $\overline{\mathrm{DP}}_{\mathrm{n}}=9$. (This $\overline{\mathrm{DP}}_{\mathrm{n}}$ is a low value). The sample was characterized by ${ }^{19} \mathrm{~F}$ and ${ }^{1} \mathrm{H}$ NMR spectroscopy. 


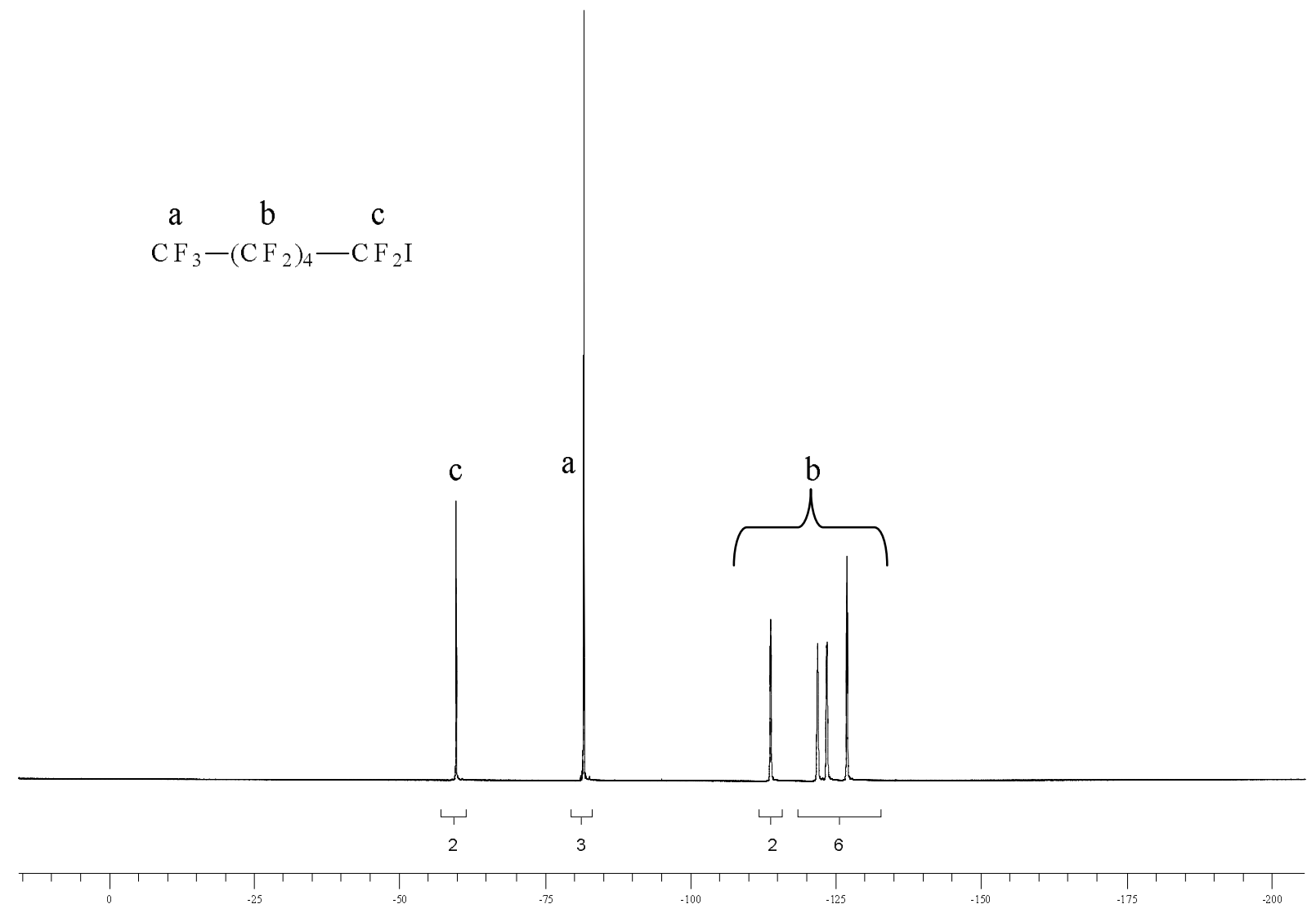

Figure 1. ${ }^{19} \mathrm{~F}$ NMR spectrum of $\mathrm{CF}_{3}-\left(\mathrm{CF}_{2}\right)_{4}-\mathrm{CF}_{2}$-I chain transfer constant (recorded in deuterated dimethylsulfoxyde, $200 \mathrm{MHz}, 298 \mathrm{~K}$,). 

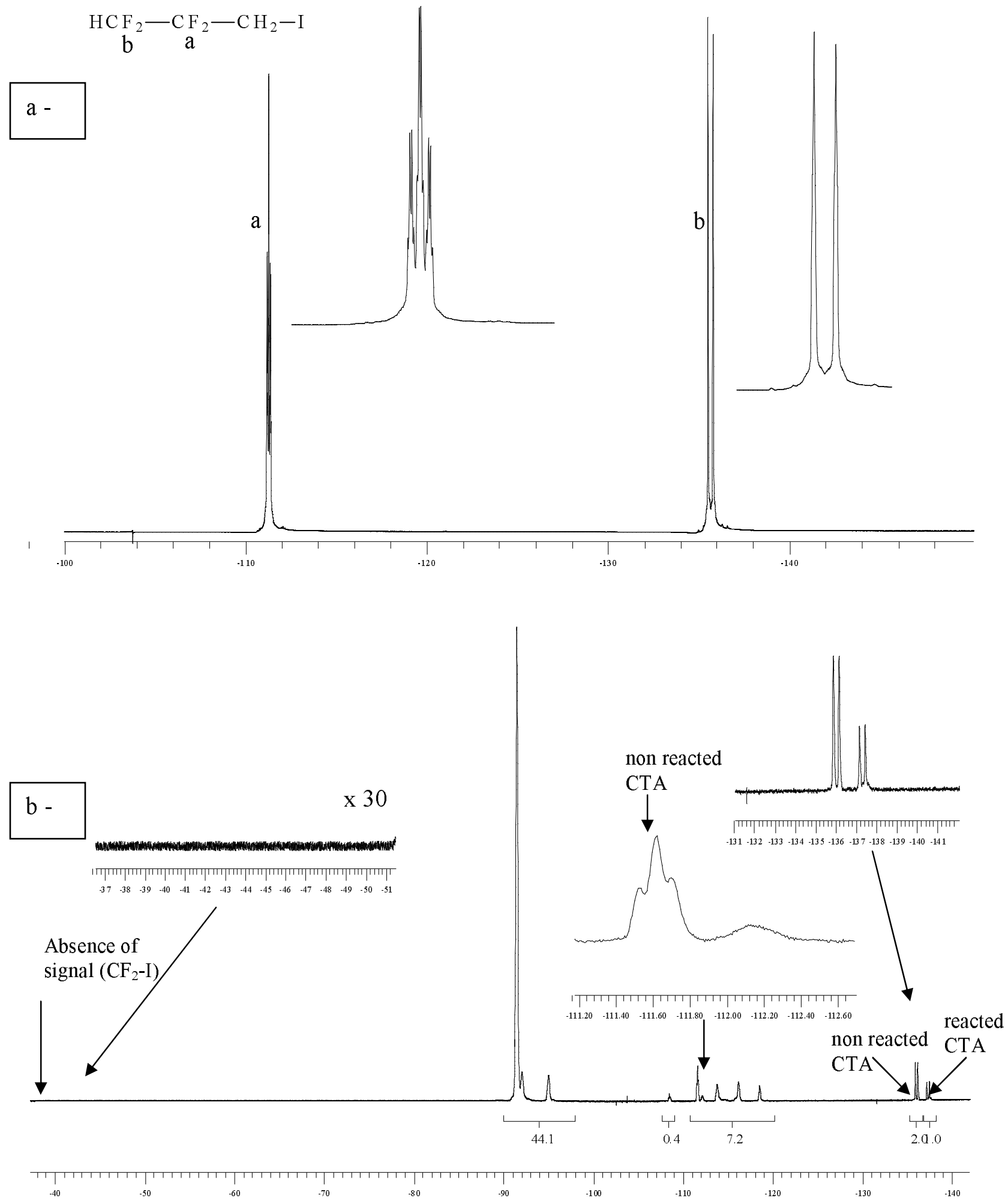

Figure 2. ${ }^{19} \mathrm{~F}$ NMR spectra of (a) $\left(\mathrm{HC}_{2} \mathrm{~F}_{4} \mathrm{CH}_{2} \mathrm{I}\right)$ chain transfer agent, (b) sample produced by iodine transfer polymerization (ITP) of vinylidene fluoride (VDF) with $\mathrm{HC}_{2} \mathrm{~F}_{4} \mathrm{CH}_{2} \mathrm{I}$ (recorded in deuterated dimethylformamide (DMF); $200 \mathrm{MHz}, 298 \mathrm{~K},\left(\overline{\mathrm{DP}}_{\mathrm{n}}=32\right)$.

Experimental conditions : ITP of VDF : $[\mathrm{VDF}]_{0}:\left[\mathrm{HC}_{2} \mathrm{~F}_{4} \mathrm{CH}_{2} \mathrm{I}_{0}:\right.$ : [2,5-bis(tertbutylperoxide)-2,5-dimethylhexane $]_{0}=100.00: 6.60: 0.66$ at $75^{\circ} \mathrm{C}$. 


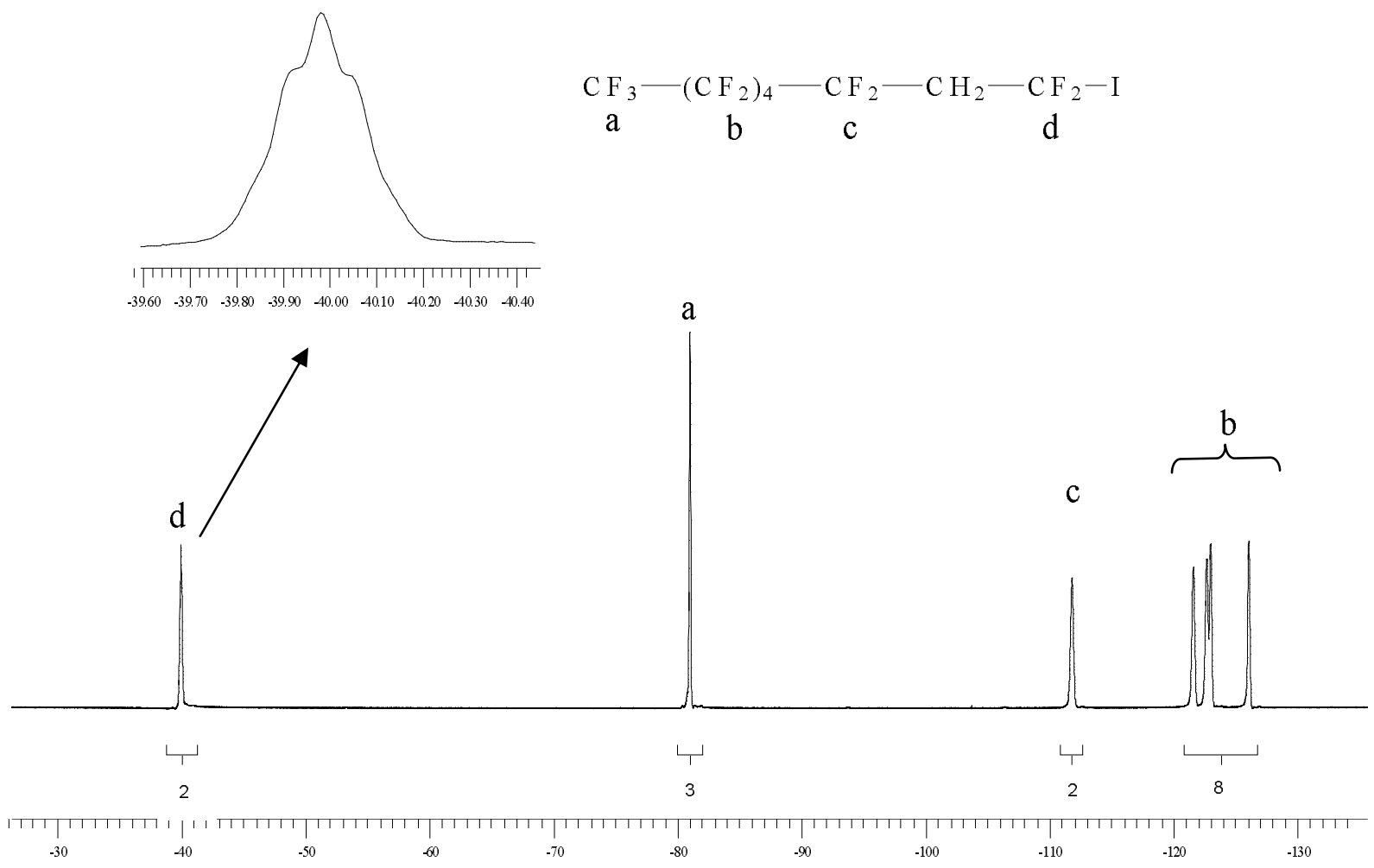

Figure 3. ${ }^{19} \mathrm{~F}$ NMR spectrum of $\mathrm{C}_{6} \mathrm{~F}_{13}-(\mathrm{VDF})_{1}-\mathrm{I}$ monoadduct $(200 \mathrm{MHz}, 298 \mathrm{~K}$, $\mathrm{CDCl}_{3}$ ). 